\title{
K problematice současného úzu paroxytonického př́ízvuku v mluvě západních a jižních Čech
}

\author{
ZBYNĚK HOLUB \\ Slezská univerzita v Opavě, Na Rybničku 626/1, CZ - 74601 Opava, \\ zbynek.holub@fpf.slu.cz
}

SCN IV/2 [2011], 5-31

\begin{abstract}
Avtor prispevka se osredinja na posebnosti naglasa (naglas na penultimi) na južnem in zahodnem Češkem, na pojav, ki ga je zabeležil v 70-80 \% ustreznih zlogov na južnem in zahodnem Češkem, severno in zahodno od Plzna. Gradivo s področij Doudleby, Manětin in južni Plzen dokazuje, da se naglas na prvem zlogu navadno bolj dosledno pojavlja na začetku dvozložnic in ustvarja naglasno-prozodično domeno s predhodnim zlogom ali nenaglašeno predpono.

In this paper the author focuses on the peculiarities of stress (referred to as "accent on the penultima") in southern and western Bohemia, a phenomenon he has documented in $70-80 \%$ of relevant syllables in southern and western Bohemia, north and west of Pilsen. The stress on the first syllable is typically more consistent at the beginning of the disyllabic word which forms a stress-prosodic domain with a previous syllable or with an unstressed proclitic, as evidenced in the Doudleby region, in the Manětín region, and south of Pilsen.
\end{abstract}

Ključne besede: naglas, besedna prozodija, penultima, južna in zahodna Češka

Key words: Stress, word prosody, penultima, south and west Bohemia

\section{K problematice prozodické typologie}

Pokud sledujeme vývoj prozodických prostředků ve slovanských jazycích, musíme se (nutně) zaměřit (kromě vývoje kvantity) rovněž na vývoj př́ízvuku a intonace. Obvykle se předpokládá, že zprvu převažoval př́izvuk dynamický, exspiratorní (podstatné byly změny v síle hlasu). Pro praslovanské období odlišujeme př́zzuk volný a pohyblivý (měnily se v průběhu flexe). Často se (v této souvislosti) diskutuje o úloze melodického prrízvuku, který se ke konci 
praslovanského období měnil zejména v jihoslovanském prostředí. Intonace pak zahrnuje především rozdíly v průběhu tónové výšky (melodii hlasu; změny výšky hlasu v rámci slabiky). Původně se zřjejmě jednalo o doprovodný fonetický příznak samohláskové kvantity, který se následně emancipoval (ovšem v sepětí s př́izvukem; prakticky se intonační rozdíly rozlišují jen v př́izvučných pozicích). Intonační poměry pak se odrazily zejména v jihoslovanských (melodicko-)př́zvukových poměrech a v délkových poměrech českých či polských. ${ }^{1}$ V tradiční prozodické analýze se o češtině předpokládá, že má fonemickou slabičnou délku, ale ne slabičnou intonaci. Počáteční př́ízvuk označuje hranice slova. Polské a slezské české dialekty ztratily samohláskové délkové rozdíly a v důsledku toho mají všeobecně poněkud silnější přízvuk na penultimě. V jižní slovanské skupině se však slabičná intonace často vyjadřovala prostřednictvím slabik (a vyjadřuje; srov. dále např. na modelu slovinštiny).

Z hlediska vokalické délky slovanská jazykověda slovanské jazyky klasifikuje bud' jako jazyky, které vokalickou délku neznají (to jsou jazyky s př́izvukem paroxytonickým ${ }^{2}$ ), k nimž se řadí i dolní lužická srbština (podobně jako polština), ${ }^{3}$ nebo jako jazyky, u nichž se pod př́ízvukem může objevit vokalická délka (to se týká i dialektů s odlišným typem silového přízvuku, než je ten, jímž se vyznačuje spisovná, popř. běžně mluvená či obecná čeština), popřr. jako typy, u nichž vokalická délka není vázána na přízvuk: např. jazyky s přízvukem iniciálním ${ }^{4}$ (kromě horní lužické srbštiny) a melodickým (specifická je situace ve slovinštině: srov. Greenberg 2003, 234-251). ${ }^{5}$

Synchronní klasifikace slovanských jazyků (a dialektů) navíc neodráží vývoj jazyka; běžně mluvený úzus českých dialektů mnohdy musíme posuzovat diachronně; a to nejen v češtině; vokalická kvantita (v souvislosti s kvalitativními rozdíly samohlásek) zanikla ve většině polských dialektů (již v 15. stol.) a v kašubštině (patrně na přelomu 16. - 17. stol.); ${ }^{6}$ naopak na českém

${ }^{1} \mathrm{~V}$ suprasegmentální rovině si tedy všímáme především základního přízvuku a melodie (přičemž tyto akustické projevy nemusí být na sobě vzájemně závislé; to platí i o projevech intonace nejen ve výpovědích, ale též při užití různých lexikálních jednotek. Stále však platí, že musíme sledovat celek výpovědi, nikoliv jenom projevy př́izvučných poměrů na jednotlivých pojmenováních). Pokud ovšem hodnotíme českou slovní prozodii, nemůžeme ani české dialekty klasifikovat jinak než jako netónové; dále je pak důležité (ne)užití př́izvuku (dynamického či melodického) ...

${ }^{2}$ Ovšem jiné jazyky (dialekty), kde vokalická délka nehraje výraznou roli (např. východoslovanské a jihoslovanské, částečně i makedonské dialekty) jsou neparoxytonické.

${ }^{3} \mathrm{~V}$ dalším výkladu se však zaměříme na reflexi zmíněného typu př́izvuku v jihočeských a v západočeských dialektech. Přičemž právě jihozápadočeské dialekty se fonemickou kvantitou vyznačují.

${ }^{4}$ Také v češtině je běžné užití slovního přízvuk na první slabice; obvyklá tvrzení o nezávislosti kvantity na přízvuku tu ovšem nejsou vždy průkazná /napřs. s ohledem na moravské dialekty apod.) ...

${ }^{5} \mathrm{~V}$ této souvislosti si dovoluji p. prof. Greenbergovi z Kansasu upřímně poděkovat za četné připomínky a podněty, $v$ jejichž rámci mne na řadu problémů přímo upozornil.

${ }^{6}$ Ale (např.) východoslovanské dialekty si udržely kvantitu až do 18 . století. 
jihu a západě nejen v I. polovině 20. století, ale v promluvách mluvčích z řad nejstarší generace prakticky dodnes přežívají typy s vyjádřenou kvantitou vokálů: slouze (zmiňoval již B. Havránek 1934: 335), pína, plíva (Sukač 2009: 175-182, Utěšený 1986: 28), minoul, sed'il (Havránek 1934: 28-33, Utěšený 1986: 34n), houmisel (tamtéž; souborněji ke vztahu kvantity a přízvuku také: Holub 2010: 20n).

Prozodické (a zejména př́ízvukové) poměry českého jihu (popř. i českého západu) se ocitly v ohnisku zájmu jazykovědců již ve 30 . letech 20 . století. V časopise Naše ř ě se věnoval intonaci české věty např. Stanislav Petř́ik, který se již v oné době zmiňuje o postojovém charakteru intonace a o její závislosti nejen na rozpoložení jedince, ale i na proměnách prostředí (včetně aktualizace; srov. již Petř́ik 1934), což je dnes (v rámci výzkumu běžně mluvené řeči) problematika veskrze aktuální.7 Obzvláště v anglosaském (v angloamerické sociolingvistice) prostředí s tím souvisí i fonologický aspekt výkladu tzv. registrů ${ }^{8} \mathrm{v}$ návaznosti na strukturalistický výklad funkčních stylů, popř. (historicky) i funkčních jazyků (z hlediska oblasti „užití jazyka“; Čermák 2001, s. 43, sekundárně: tamtéž, s. 94), a na současné pojetí jazykové stratifikace. Ve 30. letech 20. století se také na stránkách časopisu Naše řeč objevily studie o specifické melodii západočeského typu, o tzv. ,pplzeňském zpívání“. Zvukové jádro výpovědi (tj. intonační centrum - představující obvykle větný př́ízvuk) je specificky zvýrazněno. Slabika bezprostředně předcházející vlastnímu jádru má funkci intonačního vrcholu (v tónové poloze, která je výrazně zvýšena). Znamená to tedy, že se ultima (poslední slabika slova) znatelně prodlužuje; je nositelkou významného přízvuku; hovoříme též o utváření typické větné melodie. V průběhu jednoho větného úseku můžeme běžně sledovat intonační proměny (variantnost); melodie v pozici před jádrem výpovědi většinou plynule stoupá až $\mathrm{k}$ dosažení intonačního vrcholu. Následně ovšem může stagnovat, kolísat (v takovém případě se v mluvním úseku objevuje druhý intonační vrchol), klesat nebo stoupat. V žádném př́ípadě ovšem (ani následně) nepřekročí první intonační vrchol (tedy ani tehdy, navazuje-li melodie stoupavá; klesavá melodie pak zpravidla nevede k poklesu na nejnižší hlasovou úroveň, proto na výpovědi pozorujeme charakter neukončenosti; srov. Jančák 1966: 107-121, Voráč 1992: 83-84). ${ }^{9}$

${ }^{7}$ Do jisté míry uvedené problémy souvisí i s problematikou sociolingvistickou (např. s tzv. registry, rejstřiky; srov. dále; alespoň zprostředkovaně jim věnujeme pozornost i $\mathrm{v}$ hlavní části článku). Zajímavé je v tomto smyslu nejen generační odlišení mluvčích, ale též určité odlišení promluv z jihu a ze západu Čech (srov. dále ukázky výpovědí z českého jihu a západu). Také zachycení registrů by měl zohlednit připravovaný výzkum jazyka Chodska (srov. např. pozn. 24).

${ }^{8}$ Jedná se tu o pojetí variety jazyka vymezené (definované) sociální situací, např. formální, náboženskou aj., na škále všech ostatních; tedy též o rozsah stylů, stylistických prostředků (Čermák 2001: 43, 279), ale rovněž o související projevy intonačního charakteru.

9 Jančák (1966) zatím poskytuje nejpodrobnější popis slabičných intonačních proměn na vzorku textů z této oblasti (vlastně z chodských vesnic, i když se někdy hovoří o analýze „mluvy Plzně“; o tzv. plzeňském zpívání), který sestává se z 5 celých stran přesného notového záznamu (včetně melodie a rytmu) 185 promluv různé délky, které Jančák 
Na českém jihozápadě ovšem nalézáme více jevů prozodického charakteru, které jsou od obecněčeského (popř. spisovného) úzu jazyka značně odlišné. Podobně jako plzeňské zpívání sledují dialektologové na jihu Čech (popř. i na západě Čech) př́izvuk na předposlední slabice slova (tedy na penultimě), tj. př́zvuk paroxytonický, který je jinak doložený spíše v promluvách obyvatel slezských, popř. východomoravských (a snad i východočeských) lokalit, dále pak v některých lokalitách na Slovensku (zejména na pomezí Slezska, dále na severu a na východě) i (obecněji) v Polsku (v jistých pozicích i v kašubštině), ve vojvodinské rusínštině, ve východoslovanských lemkovských nářečích (dialekty Lemků v Polsku a na východním Slovensku mají fixní přízvuk na předposlední slabice) a v některých nářečích dolnolužickosrbských. ${ }^{10}$

\section{Novější výzkumy a současná teorie}

$\mathrm{V}$ dřívějších pracích jsme již reagovali na výklad v duchu teorií tzv. metatonie ${ }^{11}$. Na základě analýzy promluv rodilých mluvčích v některých jihočeských lokalitách (např. na tzv. Doudlebsku, v oblastech tzv. Blat a na širším Třeboňsku) jsme usoudili, že se tu setkáváme (především v suprasegmentální rovině, např. v rovině přízvuku) se zvýrazněním předposlední slabiky (penultimy) víceslabičných slov. Je ovšem otázkou, zda se tu jedná o přízvukování stejného typu, s jakým se setkáváme právě ve Slezsku. Pokud se tu totiž skutečně jedná o paroxynomický typ přízvuku, musíme uvažovat o jeho souvislosti s melodickou stránkou řeči; např. v porovnání se „slezským“ stavem; popř. snad též o širším akcentologickém vývoji, např̀. v porovnání s tzv. „plzeňským zpíváním“ nebo s doklady přízvuku na zájmenné př́iklonce (viděl ho ) na západě Čech a na západním okraji doudlebského regionu (na Křemežsku; srov. také výklad dále).

Jaroslav Voráč zpočátku navázal na Havránkův výklad, přičemž preferoval spíše názor o pravděpodobném archaickém původu přízvuku na penultimě v (okrajových) jihozápadočeských nářečích, který rovněž chápal jako zvláštní typ melodie (umístění melodického vrcholu) na Doudlebsku a na Prachaticku. Doplnil však další doklady z původního národnostního ostrůvku stříbrného a z Manětínska (Voráč 1955: 70).

Později už píše jednoznačně: o zbytcích archaického slovního přízvuku na předposlední slabice (slova) ve spojení s melodickým vrcholem, které jsou doloženy ve výpovědích rodilých mluvčích na jihozápadních okrajích oblasti

produkoval tím, že poslouchal dialekt z pásky a reprodukoval úroveň slabičné intonace, změn a délky (formou klavírních přehrávek). Během našeho výzkumu jsme ale dnešní rozsah výskytu tzv. „plzeňského zpívání“ nesledovali.

${ }^{10}$ Jev byl zaznamenán také již ve 30 . letech 20. století, kdy na tuto ,jihočeskou“ zvláštnost upozornil Bohuslav Havránek ve III. díle Československé vlastivědy v části Nářečí česká: Havránek 1934, s. 115-116, 155-156 (srov. výklad dále).

11 ...srov. např. Dybo 1981; dále Sukač 2011: 141-152; k jihočeským nářečím vztáhl Sukačův výklad Holub 2010: 19-21 
užívání českých nářečí v užším smyslu (s odkazem na výklad M. Romportla a na upozornění K. Horálka, že ,žádný ze slovanských jazyků, v nichž se přívuk ustálil na některé koncové slabice, nezachoval samostatnou samohláskovou kvantitu. ...Je možno dokonce mit za to, že v polštině přemístění př́zvuku z počáteční slabiky na slabiku předposlední spolurozhodovalo o zániku samostatné kvantity“ (Voráč 1976: 21). Uvádí též, že Havránkova zjištění týkající se některých okrajů jihočeských (Prachaticka a Doudlebska) doplnil podobnými údaji z některých úseků západočeských (zejména z Manětínska a z Kralovicka) - s připomínkou, že „,na celém jihozápadě bývá ... na konci slovních spojení nebo větných úsekủ prízvuk spojený s melodickým vrcholem na předposlední slabice slova, které tvoři obvykle jádro dílči výpovédi a je víceslabičné...", takže na něm spočívá „... .někdy i přizvuk větný..." (tamtéž). Na základě (tehdy) novějších výzkumů Voráč usoudil, že ..., „oblast výskytu tohoto archaismu na jihozápadě je mnohem větší, než bylo známo v dř́vější době." Odkazuje též na názor A. Lamprechta, že tento archaický stav přízvuku a melodie v jihozápadních Čechách představuje „...vývojově přechodné stadium...“ a že „...na většině jazykového území přešel ... velmi brzy z tohoto přechodného stadia na první slabiku, na rozdíl od obou okraju…" (Voráč 1976: 21-24).

Ve výše zmíněném jazykovědném svazku Jihočeské vlastivědy pak Slavomír Utěšený popisuje zvláštnosti jihozápadočeského typu přízvuku na penultimě takto:

V zachovalejších jádrech jihozápadočeské oblasti se dodnes zachoval archaický typ větné melodie $\mathrm{s}$ vrcholem na předposlední slabice kóla, která při vytýkání může být u nejstarších mluvčích doudlebského úseku zvýrazněna i silově, takže se jeví jako důrazový př́izvuk dynamický. Jde přitom o „vzorec“ melodický, který se neváže na normální přízvukové poměry a na zdůrazněném místě může stát i nepř́ízvučné slůvko; z řady př́kladů uvedených u Voráče (Voráč 1976: 21-23) citujeme: posatte se, no tak je to (Blata), bel zavřenej von i já (Stříbrsko). Podobné prŕípady uvádí i L. Švestková z Volyňska. Na Doudlebsku byly v Soběnově zachyceny např. takovéto úseky se zároveň zřetelně dynamicky zvýrazněnou předposlední slabikou: to som tu povídala ... prase začalo lítat po dvoře tule u Řezníčkù... jak je poráželi u Hejtmánků. Doklady melodického zvýraznění - tónového zvýšení předposlední slabiky na konci kól byly získány až k linii Rakovník - Příbram - Třeboň, velmi živý je pak dosud tento jev i na moravském úseku v okolí Dačic. Pozornost popisu a výkladu „př́izvučné“ jihozápadočeské předposlední slabiky věnovala řada badatelů - též v srovnávacím slovanském rámci (B. Havránek, M. Romportl, K. Horálek, A. Lamprecht, J. a L. Bachmannovi). Není-li dnešní stav jen oslabeným odrazem starších stadií, zdá se být jihozápadočeský typ záležitostí spíše jen diferencovaného regionálního vývoje v rámci zvláštních rytmomelodických typů, $\mathrm{k}$ nimž patří i tzv. plzeňské zpívání apod (Utěšený 1986: 33). ${ }^{12}$

12 Ovšem také Pavel Jančák ve svém stručném shrnutí lokálního výzkumu tzv. „plzeňského zpívání“ (1966; v poznámce 21 na s. 115) upozorňuje na př́íklad typu z Tyřovic a Skryje (jižní Křivoklátsko, tedy ze severozápadu sledované oblasti) Já tam nepolezu!, v němž se plzeňské zpívání typu ,aAC“ (i.e., a = stoupající prenucleus $+\mathrm{AC}=$ stoupající-klesající) kombinuje s melodickým stoupáním v penultimě. Tento poslední př́klad se jeví jako nejvíce frekventovaný typ. 
Vzhledem k tomu, že do dnešní doby nebyl komplexnější popis paroxynomického přízvuku pro český jih a západ podán, věnujme nyní pozornost rozdílu ve výše uvedených hodnoceních (a teprve posléze pak bude možné přejít k dokladům, které jsme získali v průběhu vlastního terénního výzkumu).

Autoři Českého jazykového atlasu (Balhar, J. a kol. /eds./, díl 5., 2005: 189; dále ČJA 5) samostatně problém přízvuku neřeší; z hlediska kvantity vokálů sledují (napřr.) formy typu kráj, spláv, které považují za novější. Upozorňuje se tu na problematiku vývoje kvantity, především pak dloužení vokálů, které může souviset s rozkolísaností a nejednotností ve vývoji přízvuku a intonace, s procesem působení různých analogií i s tendencí k náhradnímu dloužení, která se nemusela prosadit ve všech pozicích, kde k tomu byly vhodné podmínky, ale ani na celém území českého národního jazyka (ustálila se tedy jen u některých pojmenování a v některých oblastech; srov. tamtéž: ČJA 5, s. 189). Spíše než k postavení přízvuku (slovního či větného) tu lze diskutovat o oprávněnosti starších metatonických výkladů (srov. výše).

\section{K rozšírení a $\mathrm{k}$ současnému stavu výzkumu paroxytonického přízvuku}

Shrneme-li dosavadní vývoj názorů na paroxytonický př́ízvuk na českém jihu a západě, docházíme k závěru, že jediné, v čem se jazykovědci zcela shodnou, je skutečnost, že se jedná o př́ízvuk na penultimě. Původně se uvažovalo nejen o př́izvuku větném, ale i o př́zvuku slovním, jehož realizace je spojena se zvláštním typem melodie, tedy s užitím vyššího tónu, s posunem přízvuku na melodický vrchol slova (tj. s „umístěním“ tohoto vrcholu; srov. Havránek 1934: 115-116, $\left.{ }^{13} 155-156\right) ;{ }^{14}$ materiálově výklad doplnil J. Voráč, jenž upozornil na výrazně větší rozšíření jevu, než na jaké usuzoval B. Havránek (Voráč 1955: 70; 1976: 21-24, 34; později již ovšem Voráč zdůraznil, že takový přízvuk je nutno chápat i větně, nebot' tvoří víceslabičné jádro dílčí výpovědi; Voráč 1976: 21). J. Voráč dále zjistil, že ,...př́zvuk na předposlední slabice (jako melodicko-rytmický útvar) je nejzřetelnějši v doudlebských lokalitách, kdežto jinde bývá poměr složky melodické a dynamické někdy problematický..."; na ostatním jihozápadě pak usuzoval na ,reliktní melodicko-dynamickou kadenci, jejiž ustrnulý tvar se pak přenáši i na jiné připady: na koncová seskupení slov jednoslabičných nebo dokonce na úseky zakončené př́klonkou..." (zde upozorňuje na podobné souvislosti jako B. Havránek, který psal o možné souvislosti

${ }^{13}$ B. Havránek uvádí možnost, že se vedlejší přízvuk ve slově stal postupně silnější než hlavní, ale uvažuje též o starší vývojové etapě ,československého jednomístného př́zvuku“. Důležitý je zejména jeho odkaz na archaický ráz tohoto typu přízvuku. Na předposlední slabice zaznamenal vyšší tón (melodický vrchol slova) na Doudlebsku a na Prachaticku. Upozorňuje též na možnou souvislost se závěrečnou kadencí na Plzeňsku.

${ }^{14}$ Havránek opět sleduje nejvyšší tón (melodický vrchol) slova; paroxytonický přízvuk dále dokládá i na Ještědsku, kde se v té době objevovala i antepenultima. 
se „závěrečnou kadencí na Plzeňsku“; tamtéž, s. 22-23, 156). ${ }^{15}$ S. Utěšený však už o uvedeném jevu psal výlučně jako o kontextové záležitosti výpovědi, kdy usuzoval na archaický typ větné melodie (s vrcholem na předposlední slabice kóla) a zvýrazňoval i důrazový (dynamický) charakter tohoto typu přízvuku (silové zdůraznění při vytýkání zvláště na Doudlebsku). Utěšený přitom zdůrazňuje ,vzorec“" (rytmo)melodickýl6 (bez vazby na normální přízvukové poměry, mnohdy s nepřízvučným slovem na zdůrazněném místě; s odvoláním na J. Voráče 1976: 21-23; opět s odkazem na obd. jev - na tzv. plzeňské zpívání). Doklady melodického zvýraznění penultimy na konci kól posouvá nejen k výše zmíněné „severní linii“, ale (překvapivě) též na Dačicko (v souladu se svým předchozím výzkumem na českomoravském pomezí). ${ }^{17}$

Následně zjišt’ujeme, že od rozmezí 70.-80. let 20. století nebyla jihozápadočeskému typu př́izvuku na penultimě v odborných pracích věnována náležitá pozornost. Nemáme přitom nikterak v úmyslu „upozad’ovat“ úsilí týmu dialektologického oddělení ÚJČ AV ČR při zpracovávání projektu ČJA, který na dosavadní stav poznání (publikačně prezentovaný do III. čtvrtiny minulého století) navazoval. Ale popis, který nám poskytl 5. díl ČJA (kdy lze hovořit o zprávě aktuálnější snad vzhledem k roku vydání, nikoliv však př́lišs s ohledem na data sběru podkladových materiálů!), nás $\mathrm{k}$ pochopení př́íčin ustálení (a vývoje) př́zvuku na penultimě blíže neposune.

K příčinám rozšíření paroxytonického přízvuku se v minulosti vyjadřovalo více autorů. Nejčastěji byl (popř. je) považován za původně vedlejší, po zesílení pak (lokálně) hlavní (pokud došlo k přesunu přízvuku ze slabičné primy, mohlo současně dojít i k zániku vokalické kvantity), nebo za doklad archaického jazykového vývoje (S. Utěšený v této souvislosti psal o „oslabené reflexi starších období“ a o diferencovaném regionálním vývoji; ve shodě s B.

${ }^{15}$ Ve vztahu k melodické kadenci na konci slovních spojení na Plzeňsku a na Chodsku Havránek upozorňuje na skutečnost, že v takovém př́ipadě je poslední slabika značně vyšší a prodloužená (uděláme to). Obdobný př́íklad ale zachytil též na jihu Čech, na Prachaticku (zachovaný patrně v rozkaze: Hondzo, dej to sem!).

16 „Hudební stránkou“ jazyka se v minulosti nezabýval jenom L. Janáček (jak se často traduje), ale již ve 30. letech 20. století (výše zmíněný) jazykovědec S. Petřík. „Hudební aspekt" jihozápadočeského přízvuku sledoval i výše zmíněný P. Jančák (1966). Také dnes se v této oblasti nabízí řada možností pro př́ípadnou spolupráci jazykovědců (také dialektologů, ale především fonetiků) a teoretiků hudební vědy (popř. etnografü). V současné době podobně široce pojatý výzkum (bohužel) nikde neprobíhá (tedy ani v jiných oblastech uživání komplexu českého národního jazyka než na českém jihozápadě!).

${ }^{17}$ S. Utěšený ve své starší práci (1960: 56, 57n.) upozorňoval spíše na sekundární krácení vokálů ve slovech a na nestejné projevy analogie; dokonce i s dokladem rejba (srov.: Sukač 2009) a s kolísáním v rámci odlišení významu (draha $x$ dráha); v duchu metatonických výkladů se hovořilo o střídnicích za staré př́ízvučné délky ražené (v porovnání s polským typem, který vokály krátil, a s typem slovinským, kde zůstaly podle této teorie nezkráceny; srov. Utěšený 1960: 56 a Utěšený 1986: 33; ve světle současné kritiky těchto teorií: Sukač 2009). 
Havránkem a J. Voráčem porovnával sledovaný vývoj s projevy „plzeňského zpívání“. Ve shodě s jazykovědcem F. Jílkem odkazuje Utěšený na případné vztahy $\mathrm{k}$ jihoslovanskému vývoji ${ }^{18}$ ).

Zajímavým podnětem pro výklad,,jiho(západo)českého přízvuku na penultimě“ je bezesporu příspěvek, jenž upozorňuje na situaci ve slovinském dialektu rakouské oblasti v údolí řeky Gail (slovinsky Ziljska dolina; u hranice s Itálií; obd. na jihu Slovinska: Zilje), který je dodnes živý - a kterému věnoval svou práci Tijmen Pronk (2009; o. c. srov. zejména na s. 18: Like most Slovene dialects, the Potschach dialect has the accent that not only distinguishes the place of the ictus, but also the fonemic quality of the stressed vowel... a dále: ...the tonemic distinction in the Ziljsko dialect is not so much between a rising and the falling pitch, but ether between low pitched accent... and high pitched accent... tone...). Zajímavý je tu popis realizace př́ízvučného napětí mezi tónovým vyjádřením nízkým (akutovým) a vysokým (cirkumflexovým). Ve víceslabičných klíčových slovech ,ziljinského“ dialektu se tónový vrchol posouvá ve slově o dvě slabiky doprava; do celku jednoho taktu jsou však započítána i případná enklitika (jedná se tedy o taktové slovo; dále k tónovému charakteru slabik: Pronk 2009: 18 ${ }^{19}$ ). M. Greenberg následně ukazuje na paralelní situaci v jihočeském doudlebském dialektu. V takovém případě opravdu nelze vyloučit, že čeští mluvčí obvykle vnímají slovní prozodii v souladu s běžně mluvenou řečí, která se (v tomto smyslu) může od jiho(západočeského) prozodického úzu lišit, takže vnímají doudlebský př́izvuk jako $i k t \mathrm{v}$ předposlední slabice (na podobný „akutový“ př́izvuk odkazuje M. Greenberg i na příkladu goreňského nářečí v jižním Štýrsku; obd. na jihu Slovinska srov. oblast Gorenjska; v doudlebské lokalitě sleduje Greenberg tuto situaci přednostně u dlouhých slabik). V tom případě by jihočeská nářečí mohla zachovávat stopy tónových kontrastů (podrobněji Greenberg 2010: zejména s. 491). Podobně jako ve slovinském ziljinském dialektu se na jihu Čech dochovává glotálni ráz před samohláskou na začátku slova a na morfematické hranici, což vede k udržování výslovnosti bez proteze (v porovnání s jihoslovanským stavem opět Greenberg 2010: 491; podrobněji k situaci slovinských nářečí např. Greenberg 2003: 234-251).

Patrně můžeme souhlasit s Voráčovým názorem, že na větší části českého jihozápadu se uvedená melodicko-dynamická kadence na penultimě vyskytuje reliktně (popř. i v rámci jednoho či dvou následných taktů na slabice předposlední v taktu; a to dokonce i v případě, že takt končí slovem jednoslabičným či dvouslabičným); ale na Doudlebsku se o paroxytonickém prŕízvuku jako o reliktní kadenci nedá hovořit (ani dnes; vlastním výzkumem jsme podobnou situaci následně doložili také v některých lokalitách Třeboňska a na Suchdolsku!).

${ }^{18}$ Jihoslovanské jazyky jsou někdy označovány jako ,jazyky se slovní intonací“ (pitch-accent languages); kombinuje se tu přízvuk, intonace a délka. (Rovněž v této souvislosti bych rád poděkoval kol. Mgr. et Ing. Romanu Sukačovi, Ph.D., za četné konzultace a připomínky k problematice akcentologie.)

${ }^{19}$ Původní primárně př́izvučná slabika $\mathrm{v}$ tomto slovinském dialektu nese nízký tón a sekundárně přízvučná slabika nese vysoký tón. 


\section{Poznámky ke korpusu dat}

Předkládaná data reprezentují celý korpus dat; včetně statistických údajů zahrnutých do prŕílohy II. (srov. tabulky č. I. dále) a jejich upřesnění v př́íloze III. (v následných tabulkách č. II). Soubor zahrnuje všechny relevantní příklady slov s př́izvukem na předposlední slabice, které jsou dialektologicky transkribovány v rámci konkrétních kolokací (na základě materiálů zdrojového korpusu). Data jsou postupně prezentována $\mathrm{v}$ návaznosti na výklad o projevech paroxytonického př́izvuku na českém jihu a západě (nikoliv ovšem důsledně na základě příslušných kategorií v tabulkových sloupcích). Slabiky obsahující distinktivní rysy (tj. projevy zvláštního př́izvuku) jsou vyznačeny tučně.

Vybrány jen ty části výpovědi, $v$ jejichž rámci se příznakový př́ízvuk mohl projevit (bez ohledu na to, zda se skutečně realizoval na všech víceslabičných slovech, poprr. v jiných pozicích, kde by to bylo možné očekávat).

Dokonce i v př́ípadech, kdy je umístěn přízvuk na první slabice, lze (zejména na českém jihu) přepokládat, že intonační průběh melodie následuje spíše po něm (a je výrazný na následné slabice). U přízvuku na první slabice jinak $\mathrm{v}$ češtině není vždy zcela jasné, v jakém vztahu je s intonací. ${ }^{20}$

Množství zaznamenaných př́izvučných jevů je ovšem vždy přímo úměrné délce zvoleného textu; výběr mluvčích i rozsah textu tu byl většinou aleatorní (a z celkového textu vlastně vybíráme pouze ty pasáže, kde lze příznakové jevy očekávat). Zastoupení paroxytonického přízvuku (a jevů obdobného typu) v celkovém vzorku i ve výpovědích jednotlivých rodilých mluvčích bylo tedy nutné vyjádřit poměrně (tedy procentuálně).

Jako základní jednotku délky nejmenší části projevu, kterou je možné samostatně realizovat ve výpovědi, jsme zvolili slabiku (sylabu); zejména proto, že výše zmíněný Pronkův popis realizace přízvučného napětí mezi tónovým vyjádřením nízkým a vysokým (Pronk 2009: 18) ani Greenbergův názor, že čeští mluvčí vnímají doudlebský přízvuk jako $i k t \mathrm{v}$ předposlední slabice (Greenberg 2010: 490-491), nelze v jihozápadočeských podmínkách doložit bez dlouhodobého výzkumu. ${ }^{21}$ Tzv. ,počet slov“ tu jako základ statistického hodnocení přijmout nemůžeme; počet vyslovených slabik se mnohdy výrazně liší nejen v rámci jednoho lexému, ale i v rámci jednoho „vysloveného“ taktu. Navzdory předpokladu, že k tónovému zvýšení dochází před penultimou (v podstatě: na její hranici), tedy zaznamenáváme ty př́ípady, které se rodilému

${ }^{20} \mathrm{~S}$ ohledem na průběh intonace na slabice slovu s př́izvučnou primou předcházející nebo na slabice po přízvuku následující... Naopak u paroxytonického př́ízvuku lze předpokládat, že na něm vrcholí též intonace.

${ }^{21} \mathrm{~V}$ tomto príípadě hodnotíme „postavení přízvuku na slabice“; bylo by snad vhodnější přejít k „moraickému počítáni““ (které doporučuje řada badatelů). Vzhledem k tomu, že prozatím nebylo možno přikročit $\mathrm{k}$ důsledné fonetické analýze zvukových záznamů (vycházeli jsme dosud z akustického poslechu přehrávek), zůstává uvedená možnost hodnocení textu (,podle počtu mór") jedním z úkolů do budoucna, kdy předpokládáme vyžití programové (elektronické, „počítačové“) analýzy. 
českému mluvčímu (žijícímu „,mimo Doudlebsko“, pop̌r. v širším smyslu: mimo český jihozápad) jeví jako „doklady přízvuku na penultimě“.

Náš srovnávací výzkum se zaměřil na některé obce na západě a na jihu Čech; obvykle tam, kde jsme měli možnost navázat kontakt s větším počtem informantů.

Na jihu Čech probíhal dialektologický výzkum (v rámci dialektologického semináře autora tohoto prŕspěvku) již od podzimu roku 1987; v podstatě až do roku 2009, kdy bylo působení vedoucího semináře na Jihočeské univerzitě ukončeno. V létě 2010 byl proto výjezd na český jih realizován již na základě iniciativy jazykovědného oddělení Ústavu bohemistiky a knihovnictví Filozoficko-př́ŕrodovědecké fakulty Slezské univerzity v Opavě, kde nyní autor příspěvku působí. V červnu 2010 zopakoval tým odborníků (dialektologů, etymologů a akcentologů) z Kanady, USA, z Masarykovy univerity v Brně i ze Slezské univerzity v Opavě22 výzkum v lokalitách obcí Římov, Doudleby, Komařice, Lhota u Mladošovic a Bor u Suchdolu nad Lužnicí. ${ }^{23} \mathrm{~V}$ této souvislosti je nutné revidovat dřívější diskuse o „melodickém typu přízvuku“, jenž je „silově zvýrazněný na penultimě“ (srov. výše: Greenberg 2010: 490; k původnímu výzkumu dále Holub 2011a, 2011b). Dnes již ovšem nelze souhlasit (jednoznačně) ani s názorem S. Utěšeného (1986: 33), který tomuto přízvuku (na Doudlebsku) přisuzoval výrazně dynamický charakter (to platí alespoň do té doby, dokud nebude možné charakter prozodických poměrů ověřit na základě elektronické analýzy dostatečného množství zaznamenaných textů!). Uvedené přízvučné poměry byly zaznamenány téměř ve všech sledovaných obcích a také formou starších nahrávek (v Soběnově, ve Smrhově, v Křemži i jinde; kromě Ŕímova, kde se na promluvách rodilých mluvčích paroxytonický typ zatím jednoznačně prokázat nepodařilo); jednalo se vždy o uživání přízvuku slovního, nikoliv výhradně větného. A to nejenom v promluvách nejstarších mluvčích (tj. informantů nar. do r. 1945); dále uvedené zkratky (a číselné značení) jsou vysvětleny v seznamu zkratek a značek).

\section{Komařice, JK/1...}

No ale s tïm som mňela teda nákou operu; takoví pučki z bučki, to je opravdu naňic. To jen vivolá zlou krev... a ňic s toho neňi...

22 ... ve složení: prof. Dr. Marc L. Greenberg, Kansas, USA, prof. Dr. Joseph Schallert, Kanada, Mgr. Ing. Roman Sukač, Ph.D., Slezská univerzita v Opavě (akcentologové); prof. RNDr. Václav Blažek, CSc., Masarykova univerzita v Brně, ČR (etymolog), PhDr. et PaedDr. Zbyněk Holub, Ph.D., Slezská univerzita v Opavě, ČR (dialektolog).

${ }^{23} \mathrm{~S}$ ohledem na to, že většina zúčastněných se věnuje akcentologii přednostně (mnozí stojí v čele vrcholných světových institucí, které se na tento obor zaměřují) a že se jednalo o slavisty a bohemisty, lze v každém př́padě považovat jejich zjištění za relevantní. Tím spíše, že specifika místní mluvy mnohdy odhalí obvykle posluchač (tím spíše odborník), který není v lokalitě rodilým mluvčím (a u kolegů z Kanady a USA to platilo pro celé území, kde se užívá komplexu českého národního jazyka). 
Som to ud'elala tak, protože... moji mámi to bilo... jak tak on do tí sence přišel, do tí parádňi, připravení... set si na lajci... on bil s př́zñe a bil to opravdovej karakter...

\section{Doudleby, JD/2a...}

Ti tahouni se použivali po posekáňi obilí... stahovalo se to, co zbilo na zemi... a gdiš se strǔište špatňe posekalo, to tam bili ti kozi...

... vi mislite bratrrína, nebo bratrríňe... no to bilo d'ite mího bratránce, to se tag ždicki povidalo... nebo taki bil sestř́n, to taki...

... tenkrát odlišovalo podle obivatel, ja gdo gde žil, vite... Nad náma, to už bili Čecháci, a pod náma za Sobjenovem, to uš se šlo do Ňemec, to vite... A o zbiteční práci, to se taki povídalo... že jako na kazu nestluče... ono tam stejnak ňigdi ňic nenarostlo... to naše pole už bilo vječat'ejší... to se tak ř́kalo: vječat'ejši nebo menčat'ejší...

\section{Doudleby, JD/2b}

No, vařilo se, rúzȟe se vařilo, tak ňák običejňe, žádní takoví ti ekstrabuřti, jak sou lid’i neska tag zviklí.. třeba kočič́k, to sou brambori se zelím... nebo se d'elala ta, no... šafránová omáčka... třeba g objedu, diž bila slepice, tak ke slepici... dávala se tam jiška a přidával se šafrán... Ale řipná omáčka, ta bila običejná...Jo a šterc, to bilo nadrobeni fomasku, jako trhanec, to víte... ale šiški se na Vánoce d'elali z vánočkovího testa. Gdiž bili sipaní, tak se tomu řikalo perňíkář... a taki se d'elali šiški bramboroví, to víte, že jo! A ořechi bili, ňeco na hrejzáňí... abi jako bilo co hrejzat!

\section{Lhota u Mladošovic, JL/3}

Jo, tem se řikalo Tajtáňi, tem lidem, co žili na tom Vitorasku, jak se tomu taki ř́ḱká... a co sme tu pjestovali? No řipu, bilou, ta bila taki ke stravje, tu sme jedli. Ale burína, to bila... jak se tomu... krmná řepa, no... Bila červená nebo žlutá... ale támle vejš u Lužn̆ice a na Třbononsku, tam se pjestovala plucna... to bila jako... no, bilá řepa, taki...ale ne stejná jako ta u nás! Vona bila vječi neš kedlubna... bila tí kedlubňe dost podobná! Jo, a jak sem mluvil o tech Tajtánech, tak t’em... no, co žili kolem tí Lužn̆ice!... tak t’em se zas říkalo Plučňáci ...

\section{Bor u Suchdola, JB/4}

Tadi ešte negdá stari lidì řikali misto slepice právje slepjice, nebo taki lavjice... to se ešte ... od d'edečkú se to slišelo, né že né! ... A jak sme volávali na husi? No jak, tak porát stejňe: husa, husa! Ale to tak mušelo bejt i jinde, to přece nejňi ňic tag zlášňního!... jo, do lesa na jahodi, to sme chod'ili taki porád, ale to sou ti, jak se jim řiká... no, ti borúfki! ... tak... gdiš to bilo červení... no... to nebila jenom jahoda, to bilo jináč... to bila červená jahoda! A ešte bilo... jak to rostlo u teech bažin, no... já uš si to...no, černí jako jahoda, ale uvňitr bilí, no... no, to bili ti vopilki, tak se tomu řikalo... a tema borkama se topilo... to se dalo do bandaski... ňáká polífka, abi bilo ňeco $k$ objedu, to mohla bejt praženka... taki chlebofka... bramborofka taki... a šlo se!... ... a to lid’i umjeli... to bilo u Kapalú... ke Kovářum ti kluci taki chod'ili... 


\section{Soběnov, JS/5a...}

... tam má takovej vejklenek... jak tam sed’i takle smutnej... ten Kristus sedì na takovim poctafci... tak se báli, že bi se mu to rospadlo... tema dveřma že to virazili... je tam, bohoslužbi a májová pobožnost každej den... tak sme ti vjeci na tí skřriňi dali a zamkli... a bila vipáčená ta petlice... tak já nevim, kerak se tam př́dem, ale budeme to mušet nosit tak a tak... ale takovídle cení vjeci, že se nebojí na to šahat... ta kaple bejvala, ta bejvala otevřená... ale stari lid’i řikali, že se ňigda nezamikala... a ráno zvon̆ilo klekáňí, a tam bili o žňich i kuchařki...

\section{Soběnov - Malé Skaliny, JS/5b...}

... jo táta, to sme mjeli koňe... no tak sme sedlačili, a proto, diš potřeboval statek, tak sem d'elal kočího u statku, ne... sme mjeli jen koňe a kozi, a pak sem d'elal toho kočího... až do dúchodu sem mjel koňe, ale todle je d'elaní ináč... já to mám d’elaní, tudletu parádu, to se mi to... d'elalo, gdiš sem vozil pořep a tak... a hasiči, sem mušel hasit taki, a střikajčku mjeli... mjeli slavnost, tak sem dával pak taki ti lepči ohláfki, ale šag hnet nebili, co visi támle... jedni oprate a ohláfku a krouški f maštali... tak tole je ouzda... a to se ř́ká cígle... to se nechá ud'elat provizor, ono to má bejt řemínki každej zlášt'... jen tak provizorňe, maji bejt takle, abi drželi... ale cvoki sou jen cvoki, tak je to tak nepíchá, a je to!

\section{Smrhov, JSm/6...}

... a taki na každou ned'eli, to se upekl dicki bochňik chleba, a pjekní, to se d'elal dicki s tí lepši mouki... vejraška se řikalo... to je žitná mouka, ta lepčí... to se dal na stúl ten bochňik chleba f ned'eli... a mušel se nakrájet... jak to mám řict jináč... to bilo to pohošt'eňí, ešte si pamatuju... to uš nebilo, uš je to tag dávno... a tak tam prodávali $i$ ten chleba s máslem... diš tak ñáki koláče a takoví to... ale chleba s máslem, a říkávala babička, manželova babička, to že šlo nejvíc na odbit... to že nepostačili krájet, každej, vite, čerstfej chleba, bilej, pjeknej, doma upečenej, ne! ...f peci, a tak on opravdu bil dobrej, to máslo čerstfí, domácí, to bejvalo... žádni takoví visluhováňi tam nebilo... mi sme tu ešte mjeli pekárnu... to ešte bila babička, tag ho pekla babička, ale uš som tu bila, diž ho pekla... taková d'iže, násipka, a tam se navečer ud'elal kfásek, jen drobet mouki a drobed vodi a nechat... a dicki se mušel nechat od minule kousíček toho kfás-

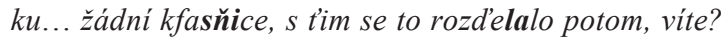

\section{Křemže, JKr/7...}

... a tag vidali kňišku, po roce devadesád vidali... tam je taki vistavovala paňi Husarová, jag d’elá ten národopis, ona d'elá krásní vjeci... šátki jak d’elala, a batiku... to neska neud'elá ňigdo, co ona d'elala... to.. ta paňi umjela... ona taki mňela tu rod'inou školu, a ti rod'ini školi mńeli tenkrát dozd velkou úroveň!... to bili zamňestnankiňe tech rúznejch podňikatelú, vite... neska sou počitače, to já už vúbec neumim... jakípak copak, ne!? A ona umjela ta paňi, umn̆ela taki dost anglicki... potom diš tadi bili f pjetaštiricátím Amerikáňi, tak oňi za ňi jako dost chod'ili, abi prekládala... ale rokama ti kontakti přešli, diš on̆i sem nejezd'ili... ta umjela višívat, dibiste vid'ela, to fšechno, cokolif... no a sem taki sokolka, ješte dneska sem sokolka, sme tadi tři, takovi starí sme, vite... on bil taki Sokol t'ech čtiricet let, ale... mi sme t'elocvičná organizace, ale oňi sou telovíchovná, vite! 
Jednotlivě pak byla v promluvách dalších rodilých mluvčích z Křemežska prokázána existence přízvuku na zájmenné prŕíklonce (vid’el ho); spíše ale na západním okraji doudlebského regionu (na Křemežsku; srov. Holub 2010: 23, dále Utěšený 1986: 33).

Na západě Čech se nám podařilo doložit stopy přízvuku na penultimě už pouze v jednotlivých výpovědích nejstarších mluvčích; většinou spíše jako přízvuk větný nebo společný silový př́ízvuk několika taktů výpovědi. Takové doklady máme spíše z lokalit položených západně a jižně od Plzně: ze Stř́ibrska, z okolí Města Touškova, z Ledcí u Horní Břízy, ze Tatiné u Žilova, z Červeného Poříćí, z Přešticka, z okolí Blovic; ze vzdálenějších míst pak především z Nečtin u Manětína (na Manětínsku již svého času prováděl výzkum J. Voráč). Řada nahrávek byla v první fázi zaznamenána posluchači oborů spojených $\mathrm{s}$ bohemistikou (v rámci terénních výjezdů, které v letech 2002-2010 pořádala nejprve katedra aplikované jazykovědy FHS a později katedra českého jazyka a literatury FPE Západočeské univerzity v Plzni, a dále v rámci sběratelských, odborných i edičních aktivit členů občanského sdružení Genius loci - Společnost pro studium života regionu, jejichž výsledkem již bylo vydání Chodského slovníku J. Jindřicha a na jejichž základě je v současné době připravováno vydání II. dílu Hruškova Dialektického slovníku chodského); proto se v současné době připravuje návazný ,akcentologický“ výjezd na Chodsko. ${ }^{24}$

Nečtiny u Manětína, ZN/1... (paní se přistěhovala z Manětína do Nečtin $\mathrm{v}$ roce 1973)

Jo d'efče, co sem neska ráno d'elala?... Já si t’i aňi nemúžu spomenout!... no, stala sem hodňe brzo, o púl štvrtí asi... to es mi nedá žánou práci, to stáváňí... no tak je pře t'ema vánocemi, no... ale zejtra to ud'elám podobňe... pak se púdu projit, abich bila čerstvá... a vařim, každej den vařim... ale nejvídz večer, to fšichňi př́dou s práce... votpoledne se taki projdu, no, a pak ud'elám večeři ... a pak se připravim k televizi... a usnu...

\section{Kšice u Stř́ibra, ZKs/2...}

... přibližila se nám doba vánočňi, tag bisme si mohli trošku popovídat o vánocích... ešte sem se nerozhodla, gdi začneme pict... mi pečeme každou prvňi sobotu f prosinci... pečeme z Vjerkou dohromadi... já to f̌̌echno namažu... a docela nám to de ot ruki!

\section{Újezd nade Mží (u Města Touškova), ZU/3...}

... to vám řeknu, slečno, to na Vánoce... to já se docela t’ešim...... jakmile ňeco je dobrí, tak to roskopou... a mi pro ti stromki musíme... to je to... až do toho lesa za boudama...

\footnotetext{
${ }^{24} \mathrm{Na}$ podzim roku 2011 se chystá vyjet do oblasti tzv. Chodska i mezinárodní vědecký tým v podobném složení, $\mathrm{v}$ jakém obdobná skupina explorátorů realizovala výzkum na jihočeském Doudlebsku v červnu roku 2010.
} 


\section{Červené Poříčí, ZC/4...}

No, kvetalo to tam... tam i maceški, kvetla i mateřidouška... to bich potřebovala, já vám ráda fšechno řeknu, ale kam teda se vidáme? ...Vid'ite, nechali mne tadi s tỉm magnet'ákem... jo venku, jak se to zmjeňilo?... ... toudle dobou už dřif sňích bil, ale letos se docela opozdil...

\section{Ledce u Horní Břízy, ZLe/5...}

... f tídle vesňici sem se taki narodila... f poledne...v malím domečku, ale pak sme se prestehovali do novího domku, kerej sme si museli společňe postavit... muj tat'ínek padl f prvňi svjetoví válce... viučil se klempírem...

\section{Tatiná u Žilova, ZT/6...}

... diš sem šla s toho našeho hotelu, tag bila krásná cest’ička ... jako ud'elaná... tam bil takovej potúček v lesich... a ti pacijenti tam ... a tam je spousta takovich klepaček... a to je... třebas na dráti...

\section{Hradišt'ská Lhotka u Blovic, ZH/7...}

... zábjer maksimáln̆e sto gramú, protože... při vjetši záteě̌i bi se moh prud zlomit... má velki hospodářski viznam... ... a štiłka obecná, to je ale riba dost dravá... třeba na pritocich...

Na nejjižnějším úseku tedy podnes nejde o reflexi specifického větného přízvuku. Vývoj př́ízvučné formy (napodobující paroxytonický přízvuk) jsme tu sledovali též na různých kombinacích jednoslabičných a dvouslabičných lexémů.

V nejjižnějším úseku českých nářečí, zejména na Doudlebsku, lze podobné přízvukové realizace doložit v dvouslabičných slovech, o nichž platí, že plynule navazují na předchozí takt (K: teda nákou, pučki z bučki, a ňic s toho neňi, mojí mámi to bilo, to už bili Čecháci, tak on do tí sence př̀̌el, on bil s přížne, no to bilo, L: tu sme jedli, jak se tomu, ale ne stejná, B: starí lid’i, porát stejňe, gdiš to bilo, jak to rostlo, tak se tomu, to se dalo, bilo ňeco, a to lid'i, S: takle smutnej, tak se báli, na tí skř́ñi, tak já nevim, mušet nosit, cení vjeci, na to šahat, že se ňigda, a tam bili, Ss: mjeli koňe, vozil pořep, hasit taki, mjeli slavnost, tak sem dával, co visí támle, tole je ouzda, a to se ř́ká cígle, mají bejt takle, Sm: bochňik chleba, to se d'elal, s tí lepši mouki, žitná mouka, mám řict jináč, chleba s máslem, ňáki koláče, chleba s máslem, čerstfej chleba, to máslo čerstfí, ěste mjeli, tag ho pekla, uš som tu bila, diž ho pekla, toho kfásku, Kr: krásní vjeci, on bil taki), nebo že jsou se „sousedícím“ (předchozím) slovem jednoslabičným součástí společného taktu (K: na lajci, D/a: na zemi, ti kozi, bil sestř́n, to taki, nad náma, pod náma, do Ňemec, to naše, D/b: tag zviklí, se zelím, to víte, L: t’em lidem, co žili, ke stravje, to bila, co žili, B: jim říká, ti klucí, S: ten Kristus, ti vjeci, a zamkli, Ss: u statku, a kozi, jen cvoki, sem d'elal, Sm: na každou, ta lepčí, ten bochňik, tag dávno, na odbit, to ešte, a nechat, 
Kr: ta paňi, dozd velkou, to fšechno), popř. (vzácněji) tu nahrazuje přízvuk na penultimě $\mathrm{v}$ jednom taktu souvislost $\mathrm{s}$ následným jednoslabičným slovem (Kr: starí sme). Někdy se však jedná o koncové seskupení slov jednoslabičných (Da: gdo gde žil, L: ta u nás, B: né že né, a šlo se, Ss: a je to, Sm: to že šlo).

Na českém západě jsme získali příznakové nahrávky (z vlastního výzkumu) blíže k Plzni, dále na Přešticku, na Blovicku, na Manětínsku a na Stř́ibrsku. Také v západním úseku českých nářečí se setkáváme s podobnými př́izvukovými realizacemi, jaké jsme doložili na jihu Čech. Je tu ovšem mnohdy složitější rozeznat podíl složky dynamické a složky melodické. Dvouslabičná slova i v promluvách rodilých mluvčích ze sledovaných lokalit někdy plynule navazovala na předchozí takt (N: stala sem hodňe, žánou práci, púdu projít, abich bila čerstvá, každej den vařim, nejvidz večer, př́dou s práce, Ks: každou prvňi, já to frsechno, to vám řeknu, U: docela t'ešim, ňeco je dobrí, C: fřechno řeknu, ale letos, Le: do novího domku, T: našeho hotelu, H: ale riba), jindy byla součástí společného taktu se slovem jednoslabičným; dvouslabičnému slovu předcházejícím (N: Jo d'efče, a usnu, Ks: ot ruki, T: na dráti, H: sto gramú, prud zlomit, a št'ika, dost dravá). I v západočeských lokalitách se vyskytla koncová seskupení slov jednoslabičných (Ks: to je to, C: dříf sňíh bil, T: a to je).

\section{Ke statistice zaznamenaných jevů}

V souboru příznakových výpovědí rodilých mluvčích máme doloženo celkem 16 textů z obou sledovaných regionů. V jihočeském regionu prezentujeme výpovědi 9 rodilých mluvčích ze 7 obcí (lokalit); po 2 promluvách (2 různých mluvčích) tedy přinášíme z obce Doudleby a z obce Soběnov. V západočeském regionu se jedná o promluvy 7 rodilých mluvčích ze 7 obcí. Počet slabik se zvláštním přízvukem (PSZP) z toho představuje (celkem) 392 slabik (326 na jihu a 66 na západě Čech; srov. v příloze II.: diagramy J-I. a Z-I., A-B; dále v tab. J-I a Z-I.).

Celkový počet slabik ve všech zachycených promluvách (CPS) činí 2543 jednotek; z toho 1998 sylabických jednotek na českém jihu (nejvíce záznamů máme ze Soběnovska, 739 slabik, a dále z Doudleb, 405 slabik) a 545 slabik na českém západě (zejména z Nečtin u Manětína: 136 slabik). V rámci zjednodušení tabulkových přehledů sledujeme ,slova s přízvukem na penultimě“ (přestože je toto hodnocení dosud nejednoznačné; srov. výklad výše; zejména zmíněný komentář M. L. Greenberga: 2010, 490-491), která v obou regionech převažují; i když výrazněji to lze sledovat spíše v jihočeském regionu (na 222 případech, zejména opět na Soběnovsku, dále v Doudlebech; na západě Čech se jedná o 38 výskytů, zejména v Nečtinách). Sestupnou tendenci můžeme sledovat na výskytu slov s přízvukem na počátku dvojslabičného slova navazujícího na předchozí takt (JčR - 52, zvláště na Soběnovsku; ZčR - 17, výrazněji opět v Nečtinách), poměrně vyrovnané jsou doklady dvouslabičných slov sousedících s predklonkou (JčR - 43, na Soběnovsku i v Doudlebech poměrně vyrovnaně; ZčR - 8, z toho 4x v Hradišt'ské Lhotce u Blovic); doklady zvýraznění přízvuku 
před přiklonkou jsou vzácné. Vzácné je i přízvučné zvýraznění předposledního slova v koncovém seskupení slov jednoslabičných (JčR - 8, ZčR - 3; srov. dále Schéma tabulkových prehledů v příloze I. a tab. I.-J a I.-Z v př́loze II. níže).

Pokud počet slabik se zvláštním přízvukem vyjádříme procentuálně (v př́íloze III.), naše výsledky se určitým způsobem změní. ${ }^{25} \mathrm{~V}$ jihočeských lokalitách dokládáme 16,3 \% př́iznakových slabik (vycházíme zde z celkového počtu slabik ve výpovědi, CPS; v Doudlebech činí tato hodnota 17,5 \%, v Soběnově dokonce $19 \%$ ), v západočeských lokalitách 12,1 \% CPS (v Újezdu nade Mží a v Tatiné u Žilova 13,3 \%, v Hradišt'ské Lhotce u Blovic téměř $13 \%$, v Ledcích u Horní Břízy 12,9 \%, v Nečtinách u Manětína 12,5 \%; srov. také diagramy J-II. a Z-II., A-C; a tabulky II.-J a II.-Z). ${ }^{26}$ Při dalším hodnocení ovšem už pracujeme nikoliv se ZS, ale se soubory výběrovými (VS). ${ }^{27}$ Slova „s př́źzvukem na penultimě“ představují v ,jihočeských“ promluvách 68,1\% (s výrazným posílením v centrálním a západním úseku Doudlebska: v Křemži $86,4 \%$, v Doudlebech až 80,6 \%, přičemž ,průměr“ tu činí 73,2 \%; ale také na jihozápadě úseku: v Boru u Suchdola nad Lužnicí 72,1 \%; jinde v regionu Doudlebska kolem $60 \%$ ). V promluvách ,západočeských“ představuje ,př́źzuk na penultimě“ 57,6 \% (výrazný je v Ledcích u Horní Břízy - 88,9 \%, ale také v Červeném Poříčí - 66,7 \%, v Kšicích u Stříbra i v Tatiné u Žilova - 62,5; jinde v regionu, např. v Nečtinách nebo v Újezdu nad Mží, se jeho zastoupení pohybuje kolem kolem $50 \%$ ); slova s prŕzvukem na počátku dvojslabičného slova navazujícího na předchozí takt činí na jihu téměř 16 \% (ale v Komařicích $35,3 \%$, na Soběnovsku až 27,8 \%), výraznější je ale tento jev na západě: 25,8 \% (ale v Nečtinách je to 41,2 \% a v Újezdu nad Mží až 37,5 \%); dvouslabičná slova sousedící s nepřízvučným jednoslabičným slovem jsou příznaková na jihu v 13,5\%, na západě v 12,1 \% (nejčastěji s předklonkou: na jihu z 97,7 \% ve VS této skupiny, na západě vždy; např. v Hradišt'ské Lhotce u Blovic v 57,1 \%!); koncová seskupení slov jednoslabičných na jihu tvoří $2,5 \%$, na západě 4,5\% (srov. s diagramy J-II. a Z-II., A až C a tabulky II.-J a II.-Z).

Slova, u nichž se projevují specifické přízvučné podmínky (,,přízvuk na penultimě“") tedy výrazně převažují v záznamech promluv z jihočeského regionu (nejen z hlediska počtu výskytů; vždy se jedná o aleatorně získaný vzorek):

${ }^{25}$ Ovšem je nutné přihlédnout k aleatornímu charakteru záznamu textů promluv; jistě je nezbytné provést $\mathrm{v}$ lokalitách českého jihu a západu souvislý návazný výzkum!

${ }^{26}$ Za hodnotu 100 \% tu chápeme oba ZS: samostatně vzorek výpovědí z jihu Čech (součet podílů příznakových jevů z jednotlivých jihočeských lokalit) a samostatně vzorek výpovědí ze západu Čech (prríznakových jevů ze západočeských lokalit). Při výpočtu zastoupení prííznakových jevů chápeme jako $1 \%$ z celku na jihu hodnotu 19, 98 (z celku 1998 výskytů, tokenů), na západě 5,45 (z celku 545 tokenů); počet „příznakových slabik“ zastoupených ve výpovědích z každého sledovaného regionu tu porovnáváme s celkovým počtem slabik v úplném vzorku z příslušného regionu (CPS).

${ }^{27} \mathrm{Za}$ hodnotu $1 \%$ tu chápeme vždy tu veličinu, která je odvozena $\mathrm{z}$ hodnocení prríslušného slabičného celku: na jihu 3,26 z celku ZS = 326 položek, na západě 0,66 z celku ZS = 66 slabik; podíly počtů slabik dokládajících jednotlivé „typy prríznakư“ tu v př́íslušném regionálním vzorku porovnáváme s celkovým počtem „příznakových slabik“. 
kolem 70 \% výskytů „,příznakových slabik“ (místy na Doudlebsku však tato hodnota převyšuje 80 \%; na západě Čech jsme zaznamenali méně ,př́íznakových slabik“, ale podíl výskytu ,př́izvuku na penultimě“ je tu místy rovněž vysoký (57,6 \% celkově, ale 88,9 \% severně od Plzně - v okolí Horní Břízy, v rozmezí 60-70 \% na Přšsticku a na Žilovsku). Zdůraznění přízvuku na první slabice, které je typické pro běžně mluvený projev na většině území České republiky, je naopak důslednější na počátku dvojslabičného slova navazujícího na předchozí takt nebo na nepřízvučnou předklonku (také na Doudlebsku, ale výrazně např. západně od Plzně na Manětínsku a jižně od Plzně na Blovicku).

\section{Závěrem}

Na českém jihu jsme mohli důsledně doložit uživání přízvuku slovního (v podstatě napříč generacemi). Na západě Čech jsme se však s přízvukem na penultimě setkali pouze $\mathrm{v}$ jednotlivých výpovědích nejstarších mluvčích (v řadě případů je opravdu potřeba uvažovat o tom, zda se nejedná o přízvuk větný nebo o společný silový přízvuk několika taktů výpovědi.

Do korpusu jsme zařadili 16 textů (promluv jednotlivých rodilých mluvčích) ze 14 obcí obou sledovaných regionů (na jihu se jednalo o 9 mluvčích ze 7 obcí, na západě o 7 mluvčích ze 7 obcí). Kromě př́ízvuku na penultimě jsme sledovali přízvuk na počátku dvojslabičného slova navazujícího na předchozí takt, postavení přízvuku v dvojslabičných slovech sousedících s nepřízvučným jednoslabičným slovem (s předklonkou nebo s prríklonkou) a přízvuk v koncovém seskupení slov jednoslabičných.

V jihočeském regionu jsme zachytili specifický př́izvuk na 326 slabikách (tj. na 16,3\% z celku jihočeského korpusu), v západočeských lokalitách na 66 slabikách (tj. na 12,1 \% z celku západočeského korpusu). V korpusu vybraných textů z jihu Čech i západu Čech jednoznačně převládl př́zvuk na penultimě (222 výskytů na jihu proti 38 výskytům na západě). Výraznější zastoupení má též ,př́ízvuk navazující na předchozí takt“" (na jihu 52 výskytů, ale na západě už jen 17 výskytů). V jihočeském regionu je také rozšířen přízvuk na počátku dvouslabičného slova po předklonce (43 výskytů). ${ }^{28}$

Vzhledem k tomu, že je množství zaznamenaných přízvučných jevů vždy přímo úměrné délce zvoleného textu (jak se zmiňujeme výše), hodnotili jsme zastoupení paroxytonického přízvuku rovněž procentuálně. Poměrné vyjádření dokládá nejvyšší výskyt př́iznakových slabik na Doudlebsku (místy více než $80 \%$ tokenů v rámci jihočeského korpusu); ze západu Čech máme dokladů méně (ale v rámci západočeského korpusu můžeme doložit (u příznakových slabik) téměř 90\% tokenů v lokalitách umístěných severně od Plzně).

${ }^{28}$ Uvádíme jen př́ípady, kdy jsme poslechem bezpečně odhalili melodickou složku př́izvuku. Mohlo by tu totiž dojít k záměně s běžným typem českého přízvuku na první slabice slova. 


\section{SEZNAM ZKRATEK A ZNAČEK}

Lokality:

J - jihočeské; Z - západočeské; JčR - jihočeský region; ZčR - západočeský region

Obce:

K - Komařice; D - Doudleby; L - Lhota u Mladošovic; B - Bor u Suchdola; S - Soběnov; Ss - Soběnov - Malé Skaliny; Sm - Smrhov; Kr - Křemže; N - Nečtiny u Manětína; Ks - Kšice u Stř́ibra; U - Újezd nade Mží (u Města Touškova); C - Červené Poříč́í Le - Ledce u Horní Břízy; T - Tatiná u Žilova; H - Hradišt'ská Lhotka u Blovic

Hodnocení souborů:

CPS - celkový počet slabik ve výpovědi

PSZP - počet slabik se zvláštním přízvukem

ZS - základní soubor

- počet slabik se zvláštním přízvukem (PSZP)

$\mathrm{VS}_{1 \text { až } 4}-$ výběrový soubor

- jednotlivé sledované typy pojmenování (s ohledem na přízvučné poměry):

- počet sledovaných typů

- procentuální vyjádření vzhledem k základnímu souboru slabik se zvláštním přízvukem

Pořadí lokalit (obcí) a výpovědí rodilých mluvčích ve vzorku celého regionu (řazení a značky):

/ - lomítko odděluje část zkratky poskytující informaci o lokalitě od části informující o posloupnosti zařazení výpovědi (a tedy též informanta nebo informantky) do souboru textů

1-7 - pořadí zaznamenané výpovědi ve vzorku v př́ślušném regionu (jihočeském nebo západočeském)

a, b - jednotliví mluvčí ve stejné obci (pokud máme v souboru výpovědí doložen př́iznakový typ př́izvučných poměrů u většího množství rodilých mluvčích v obci)

\section{LITERATURA}

Jan BALHAR a kol., 2005: Český jazykový atlas. 5. Praha: Academia.

František ČERMÁK, 2001: Jazyk a jazykověda. Praha: Pražská imaginace.

Vladimir Antonovič DYBO, 1981: Slavjanskaja akcentologija. Nauka, Moskva. 
Marc L. GREENBERG, 2010: Nova opisna slovnica ziljščine (A New Descriptive Grammar of the Zilja /Gailtal/ Dialect). Slavistična revija 58/4, 489-494. (Dostupné z http://hdl.handle.net/1808/6889).

--, 2003: Word Prosody in Slovene from a Typological Perspective. Sprachtypologie und Universalienforschung (STUF) 56/3. Focus on: Slovenian from a typological perspective. On the occasion of the International Congress of Slavicists in Ljubljana, 15-21 August 2003, ed. by Janez Orešnik \& Donald F. Reindl: 234-251. Berlin: Akademie Verlag. 234-251. (Dostupné z http://kuscholarworks.ku.edu/dspace/bitstream/1808/5245/1/MLGreenberg_STUF_2003.pdf).

Zbyněk HOLUB, 2011a: K примерам напряжения на предпоследнем слоге слова на чешском юге, в некоторых случаях на чешском западе. Русское слово. Международный сборник научных работ. III. выпуск. Волгоград: Волгоградский государственный педагогический университет. Филологический факультет. Кафедра общего и славяно-русского языкознания (V tisku).

- -, 2011b: K problematice specifických prozodických poměrů v některých lokalitách západních a jižních Čech. Sborník k uctěni 70. narozenin prof. PhDr. Viktora Viktory. CSc. Plzeň: Fraus. (V tisku).

--, 2010: Př́íspěvek k diskusi o vývoji praslovanského akcentu na pozadí prozodického systému užšího regiolektu. Genius loci českého jihozápadu. VI. Sborník z konference konané ve Studijní a vědecké knihovně v Plzni 21. a 22. října 2009. Ed. Zbyněk Holub. Plzeň: Studijní a vědecká knihovna Plzeňského kraje, Jihočeské muzeum v Českých Budějovicích a katedra českého jazyka a literatury Pedagogické fakulty Západočeské univerzity v Plzni. 20n.

Pavel JANČÁK, 1966: Západočeský intonační typ, tzv. „plzeňské zpívání“. Acta Universitatis Carolinae - Philologica 1-3. Praha: Slavica Pragensia 8. 107-121.

Stanislav PETříK, 1936: O plzeňském „zpívání“. I. Naše řeč 8, r. 20. (Dostupné z http:// nase-rec.ujc.cas.cz/archiv.php?art=3071).

- -, 1936a: O plzeňském „zpívání“. II. Domažlice. Naše řeč 9, r. 20. (Dostupné z http:// nase-rec.ujc.cas.cz/archiv.php?art=3083).

- -, 1934: K intonaci věty. Naše ř rě 9, r. 18. (Dostupné z http://nase-rec.ujc.cas.cz/ archiv.php?art=2891).

Tijmen PRONK, 2009: The Slovene Dialect of Egg and Potschach in the Gailtal, Austria. Studies in Slavic and General Linguistics, vol. 36. Amsterdam, New York: Rodopi. (Dostupné z http://linguistlist.org/issues/20/20-4401.html).

Roman SUKAČ, 2009: Paradigmatic bridge - accentual and quantitative paradigms of Czech and Slovak feminine a-stems. Czech in Formal Grammar. Eds. Dočekal, M.; Ziková, M., LINCOM. 175-182.

--, 2011: Old Czech rhythmic law. in Baltische und slavisme Prosodie. (Hrsg. Stadnik-Holzer, E.), Peter Lang Verlag. 141-152.

Slavomír UTĚŠENÝ, 1986: Nářečí v jižních Čechách. Cuřín, F. et al.: Jihočeská vlastivě$d a$. Řada A. Kultura. Jazyk. Nářečí, místní jména, slangy. České Budějovice: Jihočeské nakladatelství. 30n. 
- -, 1960: Nářeči prechodného pásu česko-moravského. Hláskosloví. Praha: Nakladatelství Československé akademie věd.

Jaroslav VORÁČ, 1992: Nářečí. Západočeská vlastivěda. Jazyk. Klimeš, Lumír a kol. eds. Plzeň: Západočeské nakladatelství (pro Pedagogickou fakultu Západočeské univerzity v Plzni). $67 \mathrm{n}$.

\section{K PROBLEMATIKI SODOBNE POJAVITVE PAROKSITONIČNEGA NAGLASA V GOVORIH ZAHODNE IN JUŽNE ČEŠKE}

V prispevku so predstavljene posebnosti naglasa (naglas na penultimi) na južnem in zahodnem Češkem. Avtor na podlagi gradiva s področij Doudleby, Manětin in južni Plzen dokazuje, da se naglas na prvem zlogu navadno bolj dosledno pojavlja na začetku dvozložnic in ustvarja naglasno-prozodično domeno s predhodnim zlogom ali nenaglašeno predpono. Na južnem Češkem ta pojav najdemo pri vseh generacijah, medtem ko je na zahodnem Češkem vzorec mogoče zaslediti le med posameznimi govorci starejše generacije in pri tem ni jasno, ali imamo opravka z besedno ali stavčno prozodijo. Poleg naglasa na penultimi je posebna pozornost namenjena tudi dvozložnim besedam, vezanim na predhodno naglasno mesto, položaju naglašenih dvozložnih besed poleg nenaglašenih enozložnih besed (s proklitiko ali enklitiko) in naglasom v zadnji skupini enozložnic. Korpus vključuje 16 besedil (naravnih govorcev) iz 14 občin dveh preučevanih pokrajin. V izbranih besedilih z južno- in zahodnočeškega področja je naglas prevladoval na penultimi (222 pojavitev na jugu, 38 na zahodu). Bolj zastopan je tudi naglas, »vezan na predhodno naglasno mesto « (52 pojavitev na jugu, 17 na zahodu). Na južnem Češkem je naglas na začetku besede podaljšan na dvozložne proklitike (43 pojavitev).

Glede na to da je količina zabeleženih naglašenih pojavov vedno v neposrednem razmerju z dolžino izbranega besedila, je avtor statistično ocenil zastopanost paroksitoničnega naglasa. Relativna izrazitost poteze je najvišja na področju Doudleby ( $>80 \%$ primerov v južnočeškem korpusu), medtem ko je na zahodnem Češkem manj dokazov. Vendar pa je bila v zahodnočeškem korpusu značilnost prisotna v skoraj $90 \%$ primerov v pokrajini severno od Plzna. 
PŘÍLOHA I.

Schéma tabulkových přehledi̊

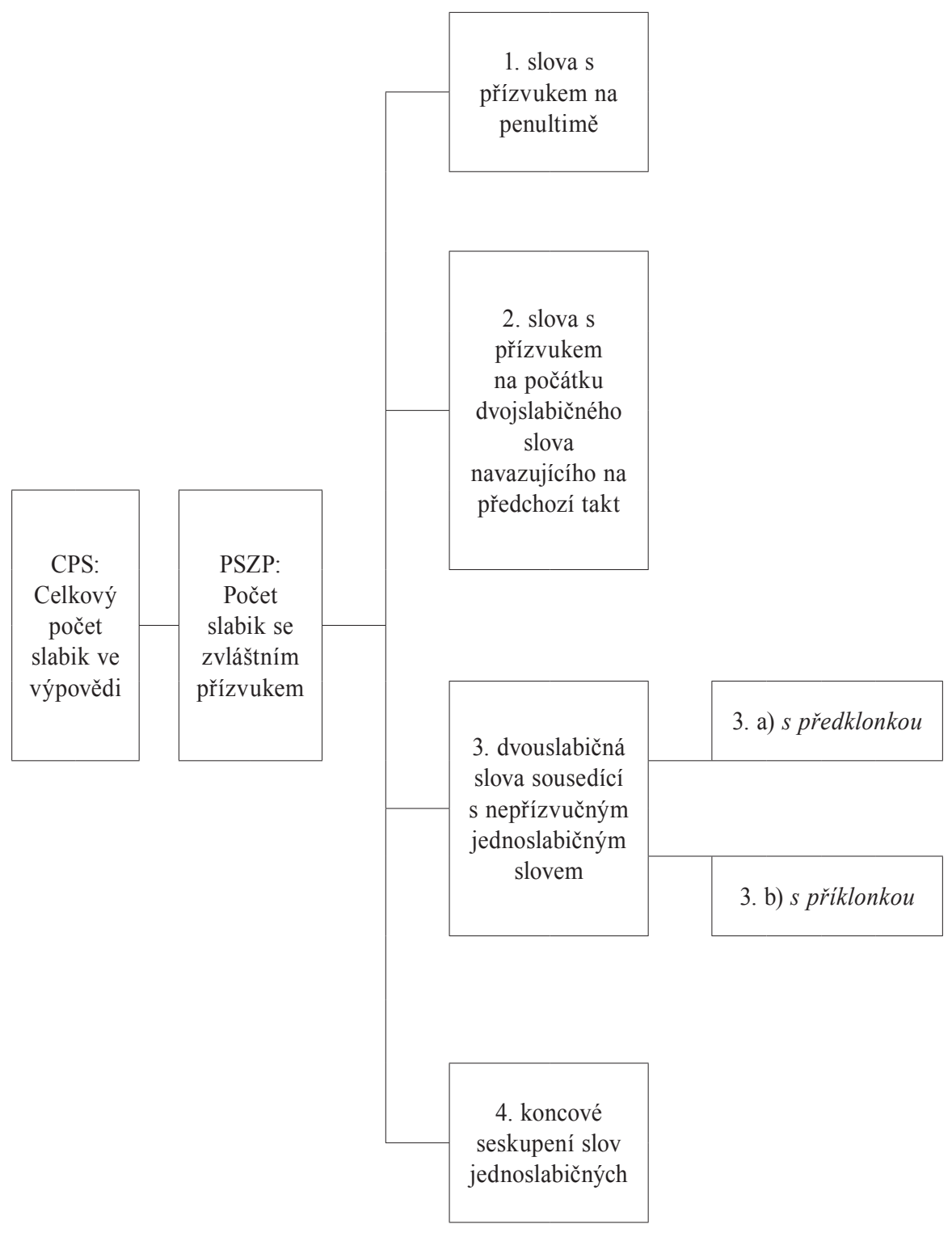


PŘÍLOHA II. Kvantitativní vyjádření počtu příznakových slabik v promluvách

Tabulka I.-J (Jihočeský region) ${ }^{29}$

\begin{tabular}{|c|c|c|c|c|c|c|c|c|}
\hline & CPS & PSZP & 1. & 2. & 3. & 3. a) & 3. b) & 4. \\
\hline JčR & 1998 & 326 & 222 & 52 & 44 & 43 & 1 & 8 \\
\hline $\mathrm{K} / 1$ & 95 & 17 & 10 & 6 & 1 & 1 & 0 & 0 \\
\hline $\mathrm{D} / 2 \mathrm{a}$ & 202 & 35 & 23 & 2 & 9 & 9 & 0 & 1 \\
\hline $\mathrm{D} / 2 \mathrm{~b}$ & 203 & 36 & 29 & 1 & 5 & 5 & 0 & 1 \\
\hline$D / 2 a+2 b$ & 405 & 71 & 52 & 3 & 14 & 14 & 0 & 2 \\
\hline $\mathrm{L} / 3$ & 177 & 26 & 16 & 3 & 6 & 6 & 0 & 1 \\
\hline $\mathrm{B} / 4$ & 279 & 43 & 31 & 8 & 2 & 2 & 0 & 2 \\
\hline $\mathrm{S} / 5 \mathrm{a}$ & 184 & 35 & 21 & 8 & 5 & 5 & 0 & 1 \\
\hline $\mathrm{Ss} / 5 \mathrm{~b}$ & 231 & 36 & 22 & 10 & 3 & 3 & 0 & 1 \\
\hline$S / 5 a+5 b$ & 415 & 71 & 43 & 18 & 8 & 8 & 0 & 2 \\
\hline $\mathrm{Sm} / 6$ & 324 & 54 & 32 & 12 & 9 & 9 & 0 & 1 \\
\hline$S / 5+6$ & 739 & 125 & 75 & 30 & 17 & 17 & 0 & 3 \\
\hline $\mathrm{Kr} / 7$ & 303 & 44 & 38 & 2 & 4 & 3 & 1 & 0 \\
\hline
\end{tabular}

Tabulka I.-Z (Západočeský region)

\begin{tabular}{|c|c|c|c|c|c|c|c|c|}
\cline { 2 - 10 } \multicolumn{1}{c|}{} & CPS & PSZP & $\mathbf{1 .}$ & $\mathbf{2 .}$ & $\mathbf{3 .}$ & $\mathbf{3 .} \boldsymbol{a})$ & $\mathbf{3 .} \boldsymbol{b})$ & $\mathbf{4}$. \\
\hline $\mathrm{ZčR}$ & $\mathbf{5 4 5}$ & $\mathbf{6 6}$ & $\mathbf{3 8}$ & $\mathbf{1 7}$ & $\mathbf{8}$ & $\mathbf{8}$ & $\mathbf{0}$ & $\mathbf{3}$ \\
\hline $\mathrm{N} / 1$ & 136 & 17 & 8 & 7 & 2 & 2 & 0 & 0 \\
\hline $\mathrm{Ks} / 2$ & 80 & 8 & 5 & 2 & 1 & 1 & 0 & 0 \\
\hline $\mathrm{U} / 3$ & 60 & 8 & 4 & 3 & 0 & 0 & 0 & 1 \\
\hline $\mathrm{C} / 4$ & 85 & 9 & 6 & 2 & 0 & 0 & 0 & 1 \\
\hline $\mathrm{Le} / 5$ & 70 & 9 & 8 & 1 & 0 & 0 & 0 & 0 \\
\hline $\mathrm{T} / 6$ & 60 & 8 & 5 & 1 & 1 & 1 & 0 & 1 \\
\hline $\mathrm{H} / 7$ & 54 & 7 & 2 & 1 & 4 & 4 & 0 & 0 \\
\hline
\end{tabular}

${ }^{29}$ Data sebraná do tabulek z lokalit na jihu a západu Čech jsou plně tu plně srovnatelná; obdobně je tomu též u souboru tabulek č. II. (srov. dále). 
Diagram J-I.A

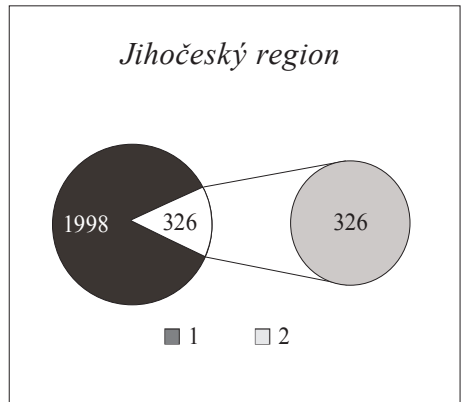

1 Celkový počet slabik ve výpovědi

2 Počet slabik se zvláštním př́izvukem
Diagram J-I.B

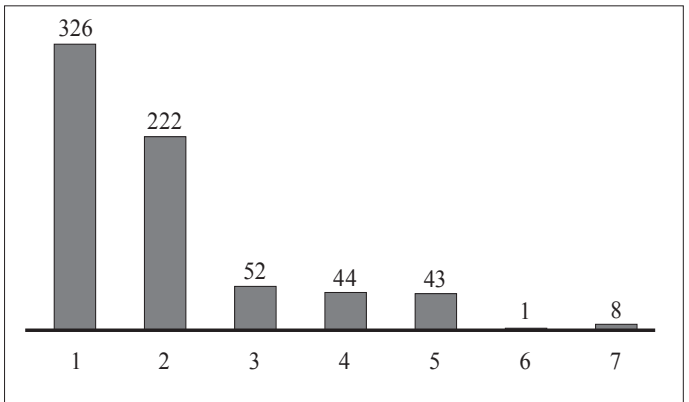

1 Počet slabik se zvláštním př́ízvukem

2 1. slova s prŕízvukem na penultimě

3 2. slova s př́izvukem na počátku dvojslabičného slova navazujícího na předchozí takt

4 3. dvouslabičná slova sousedící s nepřízvučným jednoslabičným slovem

5 3. a) s předklonkou

63 . b) s př́íklonkou

7 4. koncové seskupení slov jednoslabičných
Diagram Z-I.A

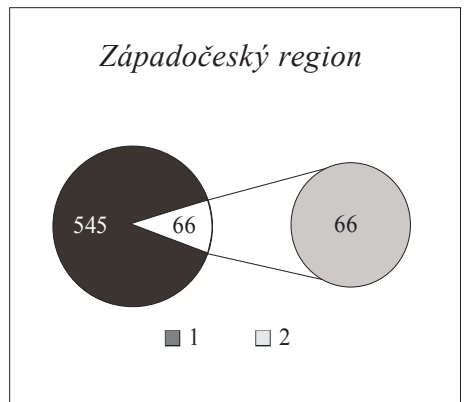

1 Celkový počet slabik ve výpovědi

2 Počet slabik se zvláštním přízvukem

\section{Diagram Z-I.B}

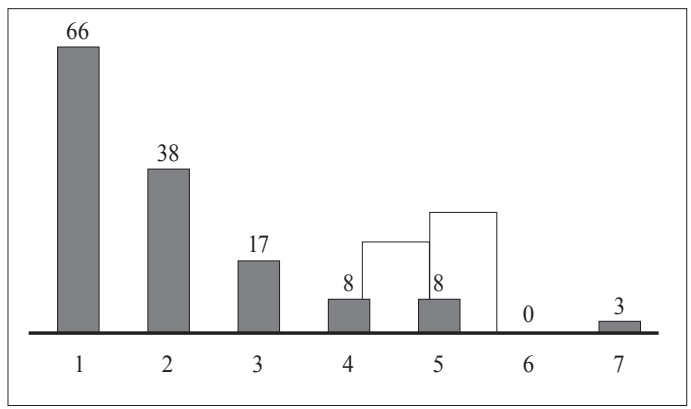

1 Počet slabik se zvláštním př́izvukem

2 1. slova s prízvukem na penultimě

3 2. slova s prrízvukem na počátku dvojslabičného slova navazujícího na předchozí takt

4 3. dvouslabičná slova sousedící s nepřízvučným jednoslabičným slovem

5 3. a) s predklonkou

6 3. b) s príklonkou

7 4. koncové seskupení slov jednoslabičných 
PŘíLOHA III. Poměrné vyjádření počtu příznakových slabik v promluvách (v \%)

\begin{tabular}{|c|c|c|c|c|c|c|c|c|c|c|c|c|c|c|c|}
\hline \multirow{2}{*}{\multicolumn{2}{|c|}{ 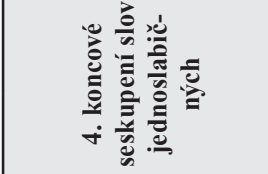 }} & $0^{50}$ & $\begin{array}{l}\text { 感 } \\
\text { ind }\end{array}$ & $\begin{array}{l}\text { ¿े } \\
\vdots \\
0^{\circ}\end{array}$ & $\begin{array}{l}\hat{n} \\
\infty \\
i\end{array}$ & $\begin{array}{l}\infty \\
\stackrel{\infty}{t} \\
i\end{array}$ & $\hat{\sigma}$ & $\begin{array}{l}0 \\
+ \\
\infty \\
\text { r }\end{array}$ & $\begin{array}{l}\vec{b} \\
\stackrel{+}{0}\end{array}$ & $\begin{array}{l}\hat{n} \\
0 \\
i\end{array}$ & 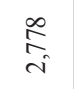 & $\begin{array}{l}\hat{\infty} \\
\stackrel{i}{i}\end{array}$ & \begin{tabular}{l}
$\widetilde{D}$ \\
\hdashline \\
-
\end{tabular} & 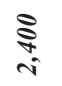 & $\begin{array}{l}0 \\
\vdots \\
0 \\
0\end{array}$ \\
\hline & & 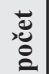 & $\infty$ & 0 & - & - & $\sim$ & - & $N$ & - & - & $\sim$ & - & $n$ & 0 \\
\hline \multirow{6}{*}{ 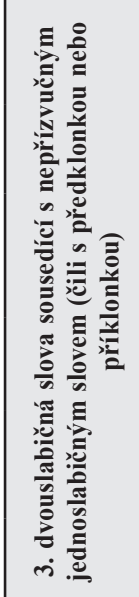 } & \multirow{2}{*}{$\frac{\sqrt{n}}{\sqrt[3]{2}}$} & $e^{0}$ & $\begin{array}{l}\underset{N}{N} \\
\text { î }\end{array}$ & $\begin{array}{l}\AA_{0} \\
0^{\prime}\end{array}$ & $\begin{array}{l}8 \\
\vdots \\
0 \\
0\end{array}$ & $\begin{array}{l}8 \\
8 \\
\circ \\
0\end{array}$ & $\begin{array}{l}8 \\
:\end{array}$ & $\begin{array}{l}8 \\
\stackrel{0}{0} \\
\circ\end{array}$ & $\begin{array}{l}8 \\
\stackrel{8}{\circ}\end{array}$ & $\begin{array}{l}\AA_{0} \\
0^{\prime}\end{array}$ & $\begin{array}{l}8 \\
\circ \\
\circ\end{array}$ & $\stackrel{8}{8}$ & $\begin{array}{l}\stackrel{8}{\circ} \\
0^{\prime}\end{array}$ & $\begin{array}{l}8 \\
8 \\
8\end{array}$ & $\begin{array}{c}0 \\
\vdots \\
i \\
i\end{array}$ \\
\hline & & 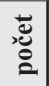 & - & 0 & 0 & 0 & 0 & 0 & 0 & 0 & 0 & 0 & 0 & 0 & - \\
\hline & \multirow{2}{*}{ 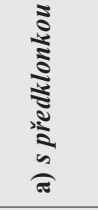 } & $e^{2}$ & $\begin{array}{l}\stackrel{\mathfrak{N}}{a} \\
\stackrel{a}{a}\end{array}$ & $\begin{array}{l}8 \\
\vdots \\
8 \\
\varrho\end{array}$ & $\begin{array}{l}\stackrel{8}{0} \\
\stackrel{-}{0}\end{array}$ & $\begin{array}{l}8 \\
\vdots \\
8 \\
\vdots\end{array}$ & : & $\begin{array}{l}8 \\
\vdots \\
\vdots\end{array}$ & $\begin{array}{l}\stackrel{8}{\circ} \\
\stackrel{8}{0}\end{array}$ & $\begin{array}{l}8 \\
\vdots \\
8 \\
\Xi\end{array}$ & $\begin{array}{l}8 \\
\vdots \\
\vdots\end{array}$ & $\begin{array}{l}\text { : } \\
\stackrel{8}{=}\end{array}$ & $\begin{array}{l}8 \\
\vdots \\
8 \\
8\end{array}$ & $\begin{array}{l}\text { : } \\
\text { : }\end{array}$ & $\begin{array}{c}8 \\
8 \\
i \\
i\end{array}$ \\
\hline & & $\begin{array}{l}\text { 芯 } \\
\text {, }\end{array}$ & 9 & - & $a$ & in & \pm & 6 & $\sim$ & $n$ & $n$ & $\infty$ & $a$ & $\approx$ & $m$ \\
\hline & \multirow{2}{*}{ 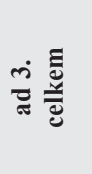 } & $e^{0}$ & $\begin{array}{l}\hat{a} \\
\vec{g} \\
\underline{2}\end{array}$ & $\begin{array}{l}\text { D } \\
\infty \\
\text { in }\end{array}$ & $\begin{array}{l}\overrightarrow{2} \\
\vec{n}\end{array}$ & 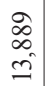 & $\underset{\hat{N}}{\stackrel{\infty}{\sim}}$ & $\begin{array}{l}\hat{S} \\
\text { ల్j }\end{array}$ & $\begin{array}{l}\overrightarrow{\widetilde{b}} \\
\dot{f}\end{array}$ & 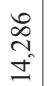 & $\widehat{\aleph}_{\infty}$ & 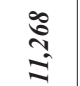 & $\begin{array}{l}\hat{8} \\
\stackrel{0}{0}\end{array}$ & $\begin{array}{l}\text { : } \\
\approx \\
\approx\end{array}$ & $\begin{array}{l}\bar{\sigma} \\
\sigma_{0}\end{array}$ \\
\hline & & 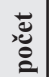 & 7 & - & $a$ & $n$ & \pm & 0 & $\sim$ & in & $m$ & $\infty$ & $a$ & $\approx$ & $\nabla$ \\
\hline \multirow{2}{*}{\multicolumn{2}{|c|}{ 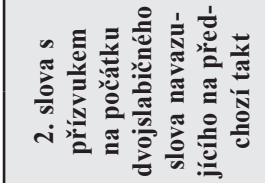 }} & $e^{0}$ & $\begin{array}{l}\vec{m} \\
\text { ŝ }\end{array}$ & 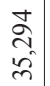 & $\underset{i}{\stackrel{t}{n}}$ & $\begin{array}{l}\infty \\
\stackrel{\infty}{\hat{\imath}} \\
i\end{array}$ & $\stackrel{\approx}{\approx}$ & $\begin{array}{l}\infty \\
\stackrel{\infty}{=} \\
=\end{array}$ & $\begin{array}{l}\text { है } \\
0 \\
\infty \\
\infty\end{array}$ & $\begin{array}{l}\tilde{n} \\
0 \\
\hat{d}\end{array}$ & 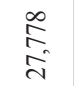 & $\begin{array}{l}\text { हे } \\
\approx \\
\approx\end{array}$ & $\begin{array}{l}\tilde{N} \\
\tilde{\mathbf{d}}\end{array}$ & $\begin{array}{l}8 \\
\text { D } \\
\text { d }\end{array}$ & 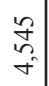 \\
\hline & & 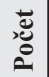 & ก & 0 & $\sim$ & - & $m$ & $m$ & $\infty$ & $\infty$ & $\varrho$ & $\approx$ & $\simeq$ & $\ddot{n}$ & $N$ \\
\hline \multirow{2}{*}{\multicolumn{2}{|c|}{ 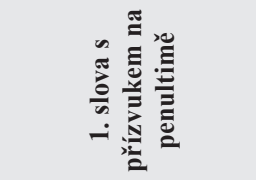 }} & $\partial^{\bar{n}}$ & $\begin{array}{l}\stackrel{\infty}{\circ} \\
\stackrel{0}{0}\end{array}$ & \begin{tabular}{c}
\multicolumn{1}{c}{} \\
$\infty$ \\
$\infty$ \\
$\infty$ \\
$n$
\end{tabular} & $\begin{array}{l}\underset{7}{*} \\
3^{n}\end{array}$ & $\begin{array}{l}0 \\
2 \\
n \\
\infty \\
\infty\end{array}$ & $\begin{array}{l}\text { సે } \\
\text { ले }\end{array}$ & 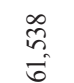 & $\begin{array}{l}\hat{o} \\
\hat{i}\end{array}$ & \begin{tabular}{|l|} 
\\
$\vdots$ \\
0 \\
8
\end{tabular} & $\begin{array}{l}\exists \\
\Xi\end{array}$ & $\begin{array}{l}3 \\
3 \\
8 \\
8\end{array}$ & 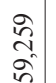 & $\begin{array}{l}8 \\
8\end{array}$ & \begin{tabular}{|l|} 
\\
0 \\
0 \\
$\infty$ \\
$\infty$ \\
0
\end{tabular} \\
\hline & & 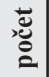 & สี & ㅇ & $\lambda$ & ते & के & $\stackrel{0}{0}$ & $\vec{m}$ & $\vec{\sim}$ & तี & 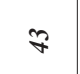 & సే & $k$ & $\stackrel{\infty}{m}$ \\
\hline \multirow{2}{*}{\multicolumn{2}{|c|}{ 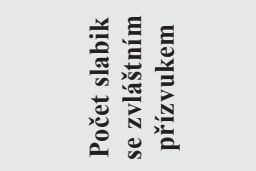 }} & $e^{\hat{N}}$ & 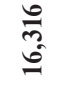 & 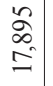 & $\begin{array}{l}\stackrel{ }{2} \\
\bumpeq\end{array}$ & $\begin{array}{l}\stackrel{ \pm}{心} \\
气 \\
=\end{array}$ & $\begin{array}{l}\sqrt{2} \\
\stackrel{2}{2}\end{array}$ & $\begin{array}{l}\stackrel{\partial}{0} \\
\text { - } \\
\text {. }\end{array}$ & $\begin{array}{l}\text { Fै } \\
\end{array}$ & $\begin{array}{l}\tilde{\delta} \\
\stackrel{\Omega}{2}\end{array}$ & 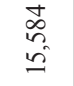 & $\stackrel{\infty}{:}$ & $\begin{array}{l}\hat{\mathbf{b}} \\
\stackrel{0}{0} \\
\varrho\end{array}$ & $\begin{array}{l}\approx \\
\vdots \\
=\end{array}$ & $\mid \begin{array}{r}\vec{n} \\
\tilde{\Xi}\end{array}$ \\
\hline & & 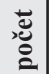 & బ్లి & $=$ & $\ddot{m}$ & ల్ల & $\pi$ & $\stackrel{\sim}{\sim}$ & $q$ & $\ddot{m}$ & ల & $\pi$ & in & 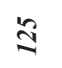 & 导 \\
\hline \multicolumn{3}{|c|}{ 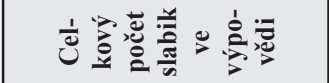 } & $\stackrel{\circ}{\circ}$ & $\approx$ & ָे & లి & $\frac{2}{9}$ & I & શે & $\stackrel{ \pm}{\infty}$ & $\vec{\sim}$ & 7 & ন্ల & ले & 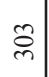 \\
\hline \multirow[b]{2}{*}{ 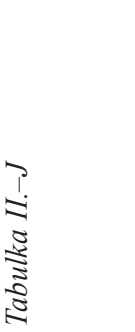 } & \multirow{2}{*}{ 䇥 } & 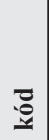 & 总 & $\vec{\nabla}$ & $\stackrel{\widetilde{N}}{\widehat{O}}$ & $\stackrel{\widehat{N}}{\hat{\theta}}$ & 离 & $\stackrel{m}{\leftrightharpoons}$ & $\vec{d}$ & $\stackrel{\tilde{n}}{\sim}$ & $\frac{\vec{n}}{w}$ & $\begin{array}{l}5 \\
\vdots \\
5 \\
\vdots \\
5 \\
5\end{array}$ & $\begin{array}{l}\text { ڤै } \\
\text { है }\end{array}$ & 克 & $\stackrel{s}{\underline{3}}$ \\
\hline & & ठัँ & 惫 & 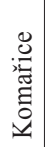 & $\begin{array}{l}\frac{\overrightarrow{0}}{0} \\
\frac{0}{\bar{z}} \\
\overline{0} \\
0\end{array}$ & & 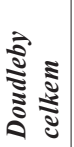 & 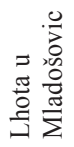 & 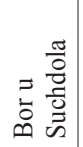 & 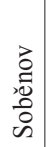 & 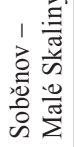 & 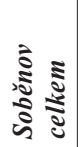 & 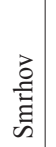 & 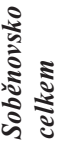 & 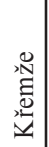 \\
\hline
\end{tabular}


Diagram J-II.A

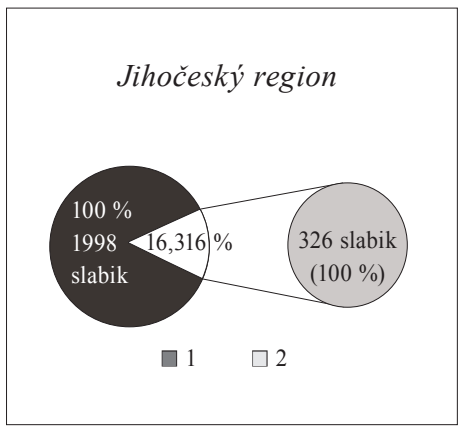

1 Celkový počet slabik ve výpovědi $\mathrm{v} \%$

2 Počet slabik se zvláštním přízvukem $v \%$ (pro sloupcový graf hodnota $100 \%$ )
Diagram J-II.B

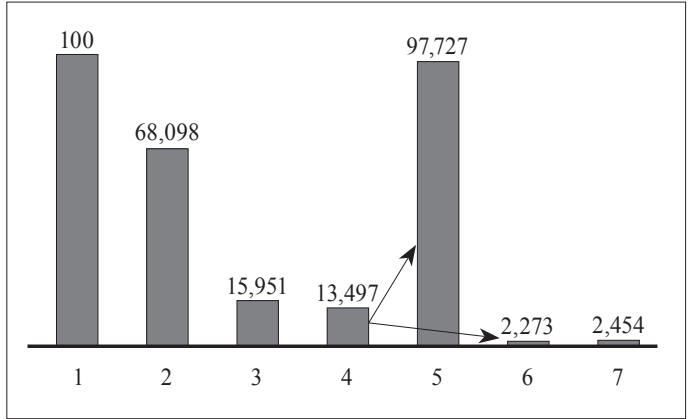

1 Počet slabik se zvláštním př́zvukem v \%

2 1. slova s př́zvukem na penultimě $v \%$

3 2. slova s př́izvukem na počátku dvojslabičného slova navazujícího na předchozí takt $\mathrm{v} \%$

4 3. dvouslabičná slova sousedící s nepřízvučným jednoslabičným slovem $\mathrm{v} \%$

5 3. a) s předklonkou $\mathrm{v} \%$

6 3. b) s př́klonkou $\mathrm{V} \%$

7 4. koncové seskupení slov jednoslabičných v \%

Diagram J-II.C

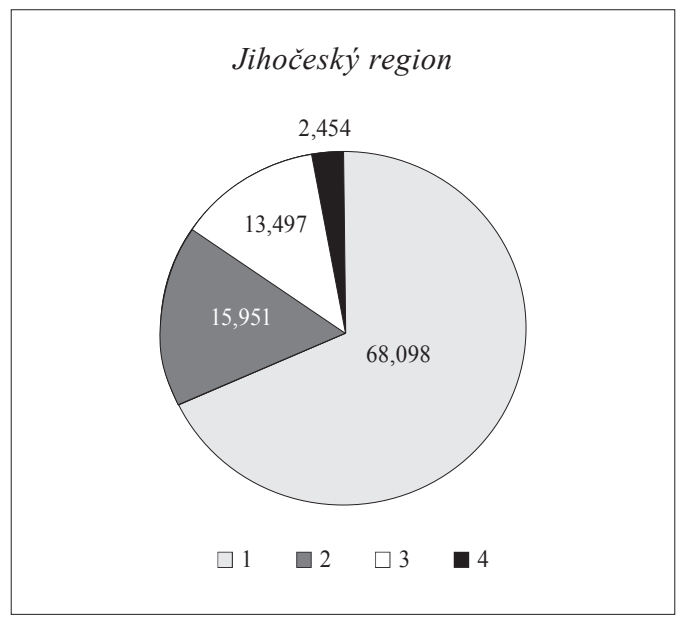

1 slova s přízvukem na penultimě v \%

2 slova s přízvukem na počátku dvojslabičného slova navazujícího na predechozí takt $\mathrm{v} \%$

3 dvouslabičná slova sousedící s neprrízvučným jednoslabičným slovem $\mathrm{v} \%$

4 koncové seskupení slov jednoslabičných v \% 
Zbyněk Holub

\begin{tabular}{|c|c|c|c|c|c|c|c|c|c|c|}
\hline \multirow{2}{*}{\multicolumn{2}{|c|}{ 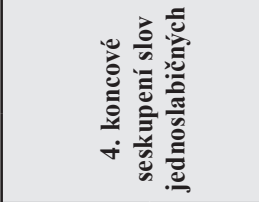 }} & $\partial^{\overrightarrow{0}}$ & 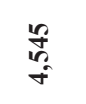 & ¿̊. & $\stackrel{8}{\circ}$ & $\begin{array}{l}8 \\
\stackrel{8}{n} \\
\text { ฯ }\end{array}$ & $\begin{array}{l}\Xi \\
\Xi\end{array}$ & $\begin{array}{l}\text { \& } \\
\vdots \\
0\end{array}$ & $\begin{array}{l}8 \\
\stackrel{5}{0} \\
\text { I }\end{array}$ & $\begin{array}{l}8 \\
\stackrel{0}{0} \\
\circ\end{array}$ \\
\hline & & 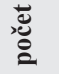 & $n$ & 0 & 0 & $\neg$ & - & 0 & - & 0 \\
\hline \multirow{6}{*}{ 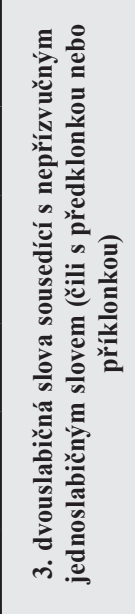 } & \multirow{2}{*}{$\frac{\sqrt{2}}{3}$} & $e^{0}$ & 气્. & ¿े. & $\stackrel{8}{\circ}$ & $\begin{array}{l}8 \\
\stackrel{-}{0}\end{array}$ & ¿ & \&̊ & \&̊. & ¿̊. \\
\hline & & 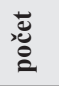 & 0 & 0 & 0 & 0 & 0 & 0 & 0 & 0 \\
\hline & \multirow{2}{*}{ 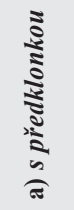 } & $\partial^{0}$ & 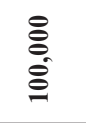 & $\begin{array}{l}8 \\
\stackrel{0}{0} \\
\vdots\end{array}$ & $\begin{array}{l}\stackrel{8}{\circ} \\
\stackrel{0}{0}\end{array}$ & $\begin{array}{l}\text { ¿ } \\
\vdots\end{array}$ & \begin{tabular}{l} 
¿ \\
\hdashline
\end{tabular} & $\begin{array}{l}8 \\
\vdots\end{array}$ & $\begin{array}{l}8 \\
8 \\
8\end{array}$ & 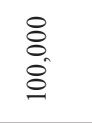 \\
\hline & & 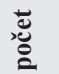 & $\infty$ & $\sim$ & - & 0 & 0 & 0 & - & $\nabla$ \\
\hline & \multirow{2}{*}{ 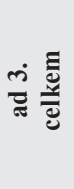 } & $0^{\infty}$ & $\stackrel{\bar{\Xi}}{\beth}$ & $\begin{array}{l}\mathfrak{2} \\
= \\
=\end{array}$ & $\begin{array}{l}\stackrel{8}{0} \\
\text { in } \\
\text { 1 }\end{array}$ & $\begin{array}{l}8 \\
\vdots \\
\circ\end{array}$ & ठ̊. & ¿̊. & $\begin{array}{l}8 \\
\stackrel{2}{0} \\
\text { i }\end{array}$ & $\underset{n}{\stackrel{q}{n}}$ \\
\hline & & 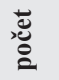 & $\infty$ & $\sim$ & - & 0 & 0 & 0 & - & $\nabla$ \\
\hline \multirow{2}{*}{\multicolumn{2}{|c|}{ 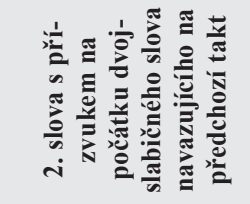 }} & $0^{0}$ & 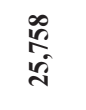 & $\begin{array}{l}\stackrel{゚}{\bumpeq} \\
\vec{F}\end{array}$ & $\begin{array}{l}8 \\
\vdots \\
i\end{array}$ & $\begin{array}{l}8 \\
\text { ñ } \\
\text { nn }\end{array}$ & 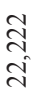 & $\begin{array}{l}\Xi \\
\Xi\end{array}$ & $\begin{array}{l}8 \\
\text { hn } \\
\text { in }\end{array}$ & $\begin{array}{l}0 \\
\stackrel{0}{1} \\
\text { I }\end{array}$ \\
\hline & & 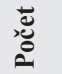 & $=$ & $r$ & $\sim$ & $n$ & $\sim$ & - & - & - \\
\hline \multirow{2}{*}{\multicolumn{2}{|c|}{ 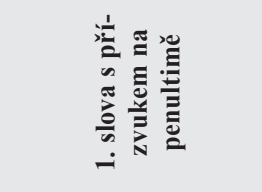 }} & $\partial^{\bar{a}}$ & $\begin{array}{l}\text { in } \\
\text { in } \\
\text { in }\end{array}$ & $\begin{array}{l}\stackrel{\mathscr{c}}{0} \\
\tilde{f}\end{array}$ & $\begin{array}{l}8 \\
\stackrel{2}{0} \\
\text { î }\end{array}$ & $\begin{array}{l}\text { \& } \\
\text { : } \\
\text { in }\end{array}$ & $\begin{array}{l}\hat{8} \\
0 \\
0 \\
0\end{array}$ & $\begin{array}{l}\infty \\
\infty \\
\infty \\
\infty\end{array}$ & $\begin{array}{l}8 \\
\stackrel{2}{0} \\
\text { in }\end{array}$ & $\begin{array}{l}\vec{i} \\
\text { a } \\
\stackrel{i}{n}\end{array}$ \\
\hline & & 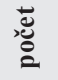 & $\stackrel{\infty}{\infty}$ & $\infty$ & $n$ & 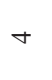 & 0 & $\infty$ & in & $\sim$ \\
\hline \multirow{2}{*}{\multicolumn{2}{|c|}{ 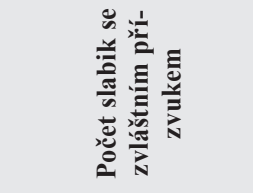 }} & $e^{3}$ & $\stackrel{\varrho}{\beth}$ & $\begin{array}{l}8 \\
\stackrel{2}{0} \\
\end{array}$ & $\stackrel{8}{\circ}$ & $\stackrel{\overbrace{}}{\stackrel{m}{=}}$ & $\begin{array}{l}\infty \\
\infty \\
\stackrel{2}{2} \\
\varrho\end{array}$ & 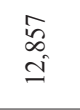 & $\stackrel{m}{m}$ & $\begin{array}{l}\text { ڤू } \\
\stackrel{-}{a}\end{array}$ \\
\hline & & 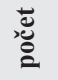 & : & $=$ & $\infty$ & $\infty$ & $a$ & $a$ & $\infty$ & $r$ \\
\hline \multicolumn{3}{|c|}{ 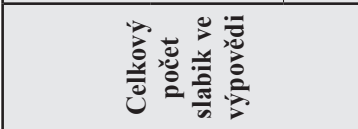 } & if & 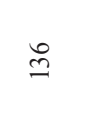 & $\infty$ & 8 & $\infty$ & 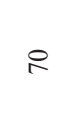 & 8 & in \\
\hline \multirow[b]{2}{*}{ 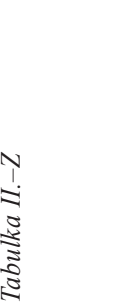 } & \multirow[b]{2}{*}{ 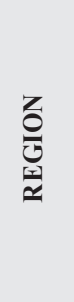 } & 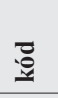 & 总 & $\overrightarrow{\mathrm{Z}}$ & $\frac{N}{\sqrt[n]{N}}$ & $\stackrel{n}{\grave{N}}$ & ভي & $\stackrel{n}{\stackrel{n}{N}}$ & $\stackrel{\bullet}{\mathrm{N}}$ & 蛋 \\
\hline & & ठ̊ & 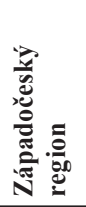 & 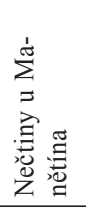 & 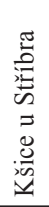 & 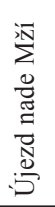 & 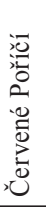 & 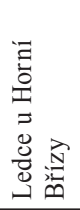 & 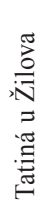 & 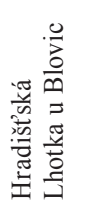 \\
\hline
\end{tabular}


Diagram Z-II.A

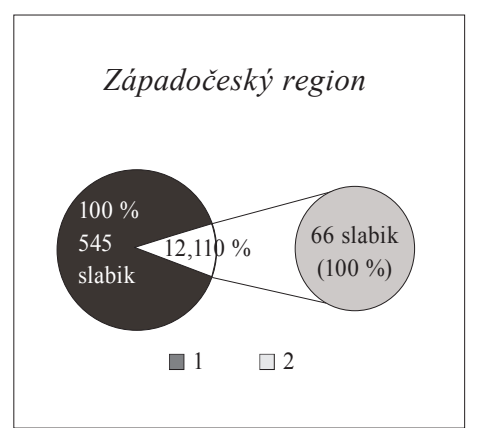

1 Celkový počet slabik ve výpovědi $\mathrm{v} \%$

2 Počet slabik se zvláštním př́izvukem v \% (pro sloupcový graf hodnota $100 \%$ )
Diagram Z-II.B

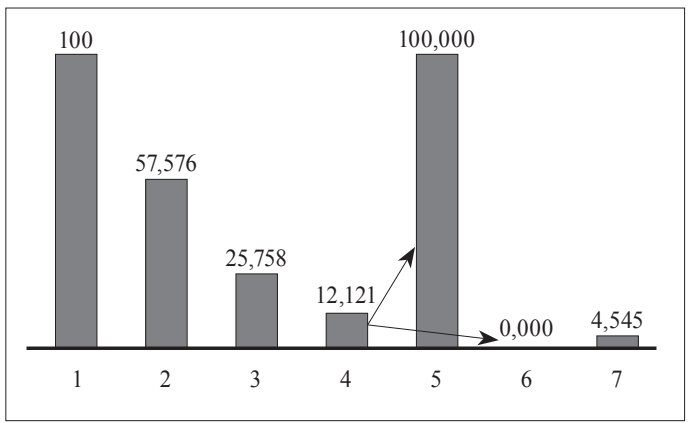

1 Počet slabik se zvláštním př́izvukem v \%

2 1. slova s př́zzukem na penultimě $v \%$

3 2. slova s př́zvukem na počátku dvojslabičného slova navazujícího na předchozí takt $\mathrm{v} \%$

4 3. dvouslabičná slova sousedící s neprrízvučným jednoslabičným slovem $\vee \%$

5 3. a) s prredklonkou $\mathrm{v} \%$

6 3. b) s př́íklonkou v \%

7 4. koncové seskupení slov jednoslabičných $\mathrm{v} \%$

Diagram Z-II.C

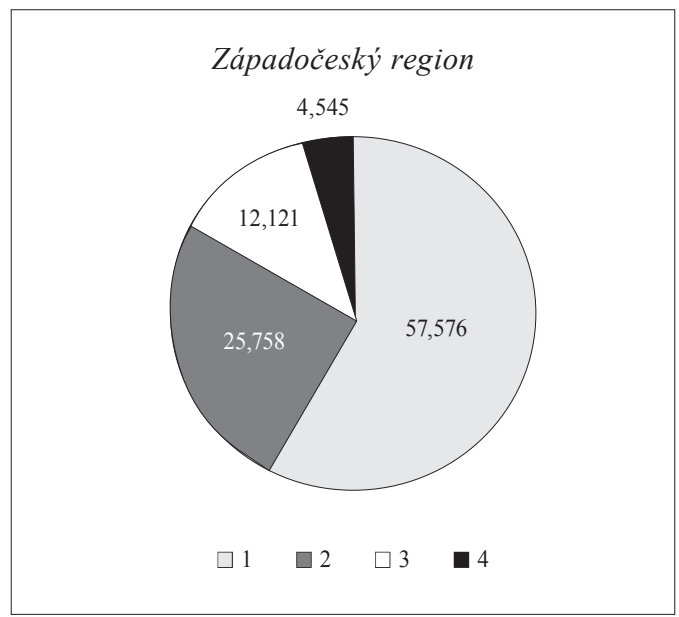

1 slova s př́ízvukem na penultimě $\mathrm{v} \%$

2 slova s př́izvukem na počátku dvojslabičného slova navazujícího na předchozí takt $\mathrm{v} \%$

3 dvouslabičná slova sousedící s nepřízvučným jednoslabičným slovem $\mathrm{v} \%$

4 koncové seskupení slov jednoslabičných v \% 